\title{
2,4-Dichlorophenoxyacetic Acid Derived Schiff Base and Its Lanthanide(III) Complexes: Synthesis, Characterization, Spectroscopic Studies, and Plant Growth Activity
}

\author{
Ganesh N. Naik, ${ }^{1}$ Raghavendra P. Bakale, ${ }^{1}$ Aishakhanam H. Pathan, ${ }^{1}$ Shashikala G. Ligade, ${ }^{2}$ \\ Shreenivas A. Desai, ${ }^{3}$ and Kalagouda B. Gudasi ${ }^{1}$ \\ ${ }^{1}$ Department of Chemistry, Karnatak University, Pavate Nagar, Karnataka, Dharwad 580003, India \\ ${ }^{2}$ Department of Botany, Karnatak Science College, Karnataka, Dharwad 580001, India \\ ${ }^{3}$ Department of Genetics and Plant Breeding, University of Agricultural Sciences, Karnataka Dharwad, 580005, India
}

Correspondence should be addressed to Kalagouda B. Gudasi; kbgudasi@gmail.com

Received 22 June 2012; Accepted 11 August 2012

Academic Editor: Neli Mintcheva

Copyright (C) 2013 Ganesh N. Naik et al. This is an open access article distributed under the Creative Commons Attribution License, which permits unrestricted use, distribution, and reproduction in any medium, provided the original work is properly cited.

2,4-Dichlorophenoxyacetic acid derived Schiff base (HL) and its lanthanide [La(III), Pr(III), Nd(III), Sm(III), Eu(III), Gd(III), Dy(III), Y(III)] complexes were synthesized and characterized by various spectroscopic $\left({ }^{1} \mathrm{H},{ }^{13} \mathrm{C}\right.$, DEPT and $2 \mathrm{D}$ HMQC NMR, FT-IR, UV-Vis, and mass) techniques and other analytical methods. HL exhibits "E" and "Z" isomerism and was confirmed by variable temperature ${ }^{1} \mathrm{H}$ NMR studies. The spectral and analytical data reveals the bidentate coordination of HL to lanthanide(III) ion, through carboxylic acid group via deprotonation. Fluorescence spectrum of europium complex shows bands at 578, 592, and $612 \mathrm{~nm}$ assignable to ${ }^{5} \mathrm{D}_{0} \rightarrow{ }^{7} \mathrm{~F}_{0},{ }^{5} \mathrm{D}_{0} \rightarrow{ }^{7} \mathrm{~F}_{1}$, and ${ }^{5} \mathrm{D}_{0} \rightarrow{ }^{7} \mathrm{~F}_{2}$, respectively. Auxin activity of HL and lanthanum(III) complex on wheat seeds (Triticum durum) was measured at different concentrations. The percentage germination, root length, and shoot length were recorded. An enhancement in the plant growth activity of the ligand was observed on complexation and the best activity was observed at $10^{-6} \mathrm{M}$ concentration.

\section{Introduction}

Rare earth elements are being used in agriculture as micronutrients and fertilizers [1-4]. These are found to have nitrogen fixing capacity, to enhance activity of hydrolytic enzymes, to promote seed germination, to strengthen photosynthetic rate, and to reduce water loss in plants $[5,6]$. Recent experiments indicate that lanthanide salts could accelerate the seed germination, increases chlorophyll content, and improve root growth $[7,8]$. These elements also found to have significant effect on the physiological and biochemical reactions in plant growth and development $[9,10]$. The effect of lanthanide(III) complexes on the growth of plants has been an important topic in agricultural field. There are only few reports which explain the auxin effect of lanthanide complexes on plant growth $[11,12]$.
Indole-3 acetic acid, naphthalene acetic acid, and 2,4dichlorophenoxyacetic acid are the well known plant growth regulating hormones, widely used in agricultural field [13, 14]. The derivatives of these hormones were also found to have plant growth regulating and other biological activities $[13,15,16]$.

Literature survey reveals that chelation of lanthanide metal ions with plant growth promoting auxins synergistically increases the plant growth [12]. Keeping this in view, we have synthesized 2,4-dichlorophenoxy acetic acid derived Schiff base and its lanthanide(III) complexes and screened for their auxin activity on wheat seeds. The work is focused on the synthesis, characterization, spectroscopic investigation, thermal, fluorescent behavior, and plant growth promoting activity of a series of rare earth complexes of 2,4dichlorophenoxy acetic acid derived Schiff base (HL). 


\section{Experimental}

2.1. Instrumentation and Materials. Elemental analyses (C, $\mathrm{H}$, and $\mathrm{N}$ ) were performed using Leco Model TruSpec CHNS analyzer. The percentage of metal content was determined according to the literature procedure [17] with xylenol orange as the indicator and EDTA as the chelating agent. SHIMADZU LCMS 2010A spectrometer is used to know the mass. Molar conductivities in DMSO $\left(10^{-3} \mathrm{M}\right)$ at room temperature were measured using an Elico conductivity bridge having platinum electrode. Melting points were determined in an open capillary on a Gallenkamp melting point apparatus and are uncorrected. IR spectra were recorded in a $\mathrm{KBr}$ matrix using an Impact-410 Nicolet (USA) FT-IR spectrometer in $4000-400 \mathrm{~cm}^{-1}$ range. The ${ }^{1} \mathrm{H},{ }^{13} \mathrm{C}$, DEPT, 2D HMQC NMR, and variable temperature ${ }^{1} \mathrm{H}$ NMR were recorded in DMSO- $\mathrm{d}_{6}$ solvent on BRUKER AV-500 MHz High Resolution Multinuclear FT-NMR spectrometer using $\mathrm{SiMe}_{4}$ as an internal standard at $\delta=0 \mathrm{ppm}$. Thermogravimetry (TG) and differential thermal analysis (DTA) were run in nitrogen atmosphere in a temperature range of $20^{\circ} \mathrm{C}$ to

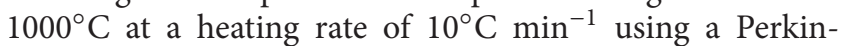
Elmer (Pyris Diamond) analyzer. UV-Visible spectra were recorded on a CARY 50 Bio UV-Visible spectrophotometer in $200-1100 \mathrm{~nm}$ range in DMSO solvent. Fluorescence spectrum was measured on F-7000 FL spectrophotometer. Plant growth activity was performed in a dual chamber seed germinator at $25^{\circ} \mathrm{C}$ temperature and $70 \pm 5 \%$ humidity with proper illumination.

2,4-Dichlorophenoxyacetic acid and 2-formyl phenoxyacetic acid were obtained from Sigma Aldrich. Lanthanide(III) oxides were procured from Indian Rare Earths Ltd, India. Other chemicals were obtained from s.d. Fine Chemicals, India, and used as received. Solvents were purified by standard methods [18]. Lanthanide nitrates were prepared by dissolving the corresponding oxide $(99.99 \%$,) in $50 \%$ $\mathrm{HNO}_{3}$ followed by evaporation of the excess acid. All the compounds were routinely checked by thin-layer chromatography (TLC) on aluminum-backed silica gel plates. The wheat seeds (Triticum durum) DWR-2006 were collected from University of Agricultural Sciences (UAS), Dharwad, India.

\subsection{Synthesis}

2.2.1. Synthesis of 2-\{[2-(2, 4-Dichloro-phenoxy)-Acetyl]Hydrazonomethyl\}-Phenoxy)-Acetic Acid (HL). A mixture of 2,4-dichlorophenoxyacetic acid (1) (12 g, $54.28 \mathrm{mmol})$ and concentrated $\mathrm{H}_{2} \mathrm{SO}_{4}(4 \mathrm{~mL})$ in dry methanol $(50 \mathrm{~mL})$ was refluxed for $15 \mathrm{hrs}$ to yield the 2,4-dichlorophenoxy acetic acid methyl ester (2). Product was separated and purified. To the methanolic solution of 2, (8 g, $34.03 \mathrm{mmol})$, hydrazine hydrate $(3 \mathrm{~g}, 44.08 \mathrm{mmol})$ was added slowly and stirred for $30 \mathrm{~min}$. The 2,4-dichlorophenoxyacetic acid hydrazide separated (3) was filtered and washed with methanol. The hydrazide (3) (7 gm, $29.77 \mathrm{mmol})$ was stirred with 2formyl phenoxy acetic acid (4) $(5.36 \mathrm{~g}, 29.77 \mathrm{mmol})$ in THF $(75 \mathrm{~mL})$ for $30 \mathrm{~min}$ and the product formed was filtered and washed thoroughly with THF to obtain 2-\{[2-(2,4-dichlorophenoxy)-acetyl]-hydrazonomethyl $\}$-phenoxy)-acetic acid (HL) (5). Yield: $90 \%$, M.P: $233-235^{\circ} \mathrm{C}$.

${ }^{1} \mathrm{H}$ NMR (DMSO- $\left.\mathrm{d}_{6}, \mathrm{ppm}\right): 4.82,4.90$ (s, 2H, C2H/ $\left.\mathrm{C}^{\prime} H\right), 4.80,5.31$ (s, 2H, C11H/C11'H), 6.97, 7.01 (d, $\left.1 \mathrm{H}, J=9.4 \mathrm{~Hz}, \mathrm{C} 4 \mathrm{H} / \mathrm{C}^{\prime} \mathrm{H}\right), 7.03,7.08(\mathrm{~d}, 1 \mathrm{H}, J=6.4 \mathrm{~Hz}$, $\left.\mathrm{C} 17 \mathrm{H} / \mathrm{C} 17^{\prime} H\right), 7.11,7.17\left(\mathrm{~d}, 1 \mathrm{H}, J=6.4 \mathrm{~Hz}, \mathrm{C} 16 H / \mathrm{C} 16^{\prime} H\right)$, 7.32-7.41 (m, 2H, C14H/C14 ${ }^{\prime} H$ and $\left.\mathrm{C} 5 H / \mathrm{C}^{\prime} H\right), 7.57,7.61$ (d, $\left.1 \mathrm{H}, J=5 \mathrm{~Hz}, \mathrm{C} 7 \mathrm{H} / \mathrm{C}^{\prime} \mathrm{H}\right), 7.83-7.90\left(\mathrm{~m}, 1 \mathrm{H}, \mathrm{C} 6 \mathrm{H} / \mathrm{C6}^{\prime} H\right)$, 8.42, 8.65 (s, 1H, C9H/C9' $H), 11.72,11.80\left(1 \mathrm{H}, \mathrm{NH} / \mathrm{N}^{\prime} H\right)$, $13.16(\mathrm{~s}, 1 \mathrm{H}, \mathrm{OH})$.

${ }^{13} \mathrm{C}$ NMR (DMSO-d $\left.\mathrm{d}_{6}, \mathrm{ppm}\right): 64.62,64.75\left(\mathrm{C} 2 / \mathrm{C}^{\prime}\right)$, 64.67, 66.91 (C11/C11'), 112.47, $112.84\left(C 4 / C 4^{\prime}\right), 114.97$, 115.12 (C17/C17'), 116.15, $117.13\left(\mathrm{C} 8 / \mathrm{C}^{\prime}\right)$, 121.01, $121.03\left(\mathrm{C} 16 / \mathrm{C} 16^{\prime}\right), 122.02,122.20\left(\mathrm{C} 13 / \mathrm{C} 13^{\prime}\right), 124.38$, $124.94\left(C 6 / C 6^{\prime}\right), 125.58,125.77\left(C 15 / C 15^{\prime}\right), 127.75,127.96$ (C5/C5 $\left.{ }^{\prime}\right), 129.12,129.30$ (C7/C7'), 131.15, $131.44\left(C 14 / C 14^{\prime}\right)$, 139.00, 143.00 (C9/C9'), 152.54, $152.73\left(C 12 / C 12^{\prime}\right), 156.08$, $156.20\left(C 3 / \mathrm{C3}^{\prime}\right), 163.28,168.12\left(\mathrm{C} 10 / \mathrm{C} 10^{\prime}\right), 169.88,169.94$ $\left(C 1 / C 1^{\prime}\right)$.

2.2.2. General Procedure for the Synthesis of Lanthanide Complexes. The complexes were prepared by treating HL with freshly prepared lanthanide(III) nitrates in presence of triethyl amine according to literature procedure [19] with slight modifications. The mixture of HL ( $0.5 \mathrm{gm}, 1.26 \mathrm{mmol})$ and triethyl amine $(0.14 \mathrm{~g}, 1.38 \mathrm{mmol})$ was taken in THF $(50 \mathrm{~mL})$ and stirred till HL completely dissolves. To this solution, freshly prepared $\mathrm{Ln}\left(\mathrm{NO}_{3}\right)_{3}(0.42 \mathrm{mmol})(\mathrm{Ln}=\mathrm{La}$, $\mathrm{Pr}, \mathrm{Nd}, \mathrm{Sm}, \mathrm{Eu}, \mathrm{Gd}, \mathrm{Dy}, \mathrm{Y})$ was added slowly under stirring and was further refluxed for $2 \mathrm{hrs}$. Solvent was evaporated under reduced pressure. The solid obtained was washed with water and THF several times. The product was dried under vacuum. Yield: $60-70 \%$.

${ }^{1} \mathrm{H}$ NMR of lanthanum(III) complex (DMSO- $\left.\mathrm{d}_{6}, \mathrm{ppm}\right)$ : $4.70(\mathrm{~s}, 2 \mathrm{H}, \mathrm{C} 2 \mathrm{H}), 5.28(\mathrm{~s}, 2 \mathrm{H}, \mathrm{C} 11 \mathrm{H}), 6.92(\mathrm{~d}, 1 \mathrm{H}, J=9.2 \mathrm{~Hz}$, $\mathrm{C} 4 \mathrm{H}), 7.10(\mathrm{~d}, 1 \mathrm{H}, J=6.3 \mathrm{~Hz}, \mathrm{C} 16 H), 7.25(\mathrm{~d}, 1 \mathrm{H}, J=6.3 \mathrm{~Hz}$, $\mathrm{C} 17 \mathrm{H}), 7.39$ (m, 1H, C5H), 7.40 (s, 1H, C14H), 7.56 (d, 1H, J $=9.2 \mathrm{~Hz}, \mathrm{C} 7 \mathrm{H}), 7.86-7.90(\mathrm{~m}, 1 \mathrm{H}, \mathrm{C} 6 \mathrm{H}), 8.41(\mathrm{~s}, 1 \mathrm{H}, \mathrm{C} 9 H)$, $11.64(1 \mathrm{H}, \mathrm{NH})$.

${ }^{13} \mathrm{C}$ NMR lanthanum(III) complex (DMSO-d, ppm): 66.91 (C11), 67.55 (C2), 112.47 (C4), 115.28 (C17), 117.13 (C8), 122.13 (C13), 122.25 (C16), 124.30 (C15), 126.92 (C6), 127.96 (C5), 129.12 (C7), 131.90 (C14), 138.50 (C9), 153.00 (C12), 156.08, (C3), 164.30 (C10), 176.46 (C1).

2.3. Protocol for the Plant Growth Activity on Wheat Seeds. DWR-2006 (Triticum durum), a local variety of wheat seeds developed at University of Agricultural Sciences, Dharwad, India, was selected to investigate the growth activities of the synthesized compounds. The solutions of HL, lanthanum(III) complex, $\mathrm{La}\left(\mathrm{NO}_{3}\right)_{3}$, and 2,4-dichlorophenoxyacetic acid were prepared by dissolving them in minimum quantity of DMSO $(\sim 1 \mathrm{~mL})$ and further diluted with distilled water to obtain the solutions of $1 \times 10^{-5} \mathrm{M}, 1 \times 10^{-6} \mathrm{M}$ and, $1 \times$ $10^{-7} \mathrm{M}$ concentrations. Seed germination experiments were carried out according to the literature method [20] with slight modifications. Healthy wheat seeds were selected and 


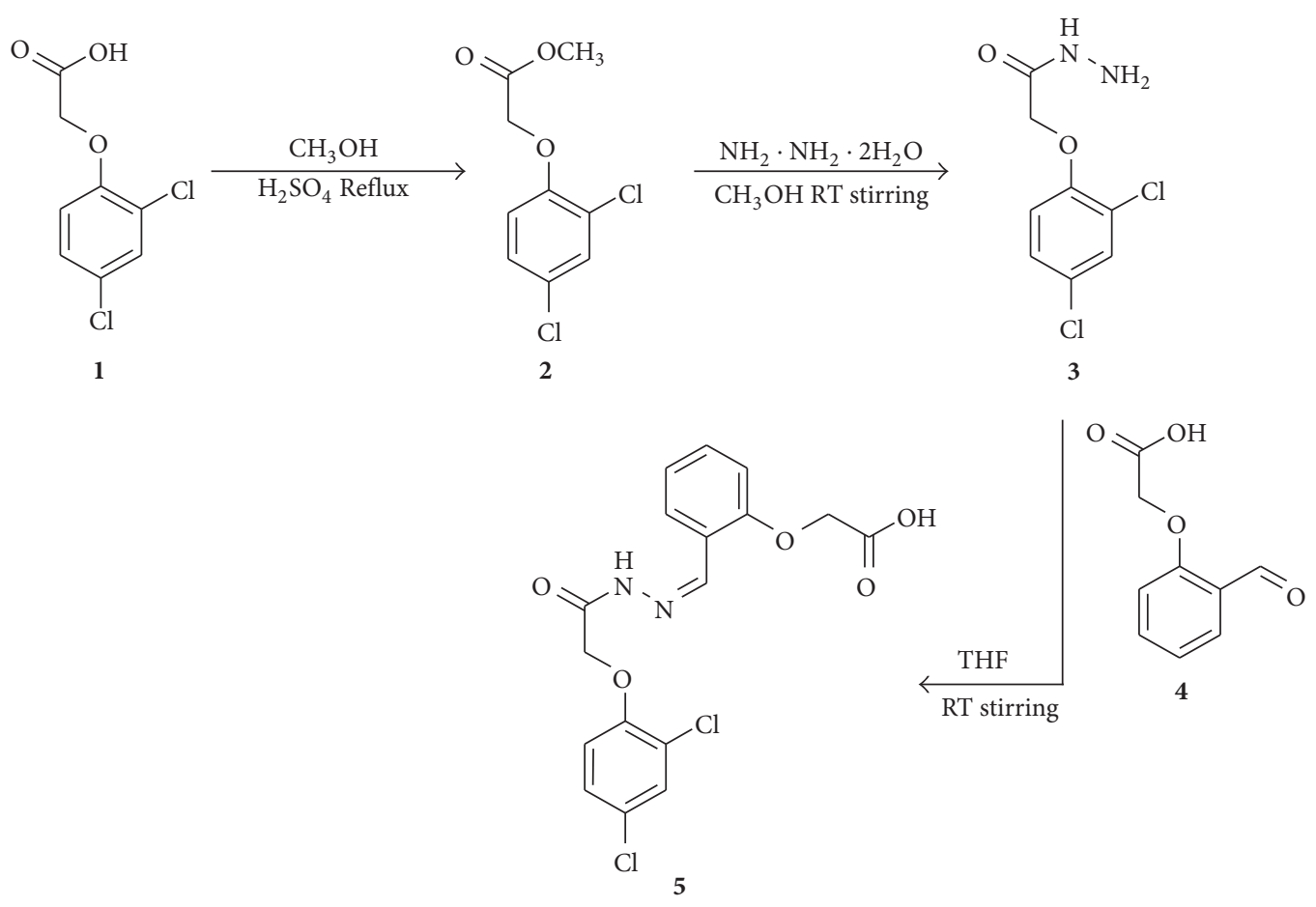

SCHEME 1: Synthetic route for the preparation of HL.

washed with distilled water before soaking in test solutions. Hundred seeds were soaked in test solutions of particular concentration for 3 minutes and then arranged on the moistened specially prepared germination paper placed on polythene sheet. One more moistened germination paper was placed over the seeds and loosely rolled. Each roll was labeled clearly and kept upright in the seed germinator and maintained at $25^{\circ} \mathrm{C}$ temperature and $70 \pm 5 \%$ humidity, with proper illumination. The conditions were maintained for eight days. After eight days, percentage germination was calculated. Further, 10 seeds were randomly selected from each roll for root and shoot length measurements. The experiments were performed in triplicate.

2.3.1. Statistical Analysis. The results are evaluated with SPSS (Statistical Package for Social Science, Windows, version 17.0) packed program. One way ANOVA with Duncan statistical analysis with significance at $P<0.05$ was used for data analysis.

\section{Results and Discussions}

The Schiff base (HL) was prepared as shown in Scheme 1. The structure of HL was confirmed by IR, NMR, and mass spectral analysis. All the complexes were obtained in moderate to good yields $(60-70 \%)$ by reacting HL and lanthanide(III) nitrates in THF in 3:1 (ligand to metal) molar ratio. The complexes are soluble in DMSO and DMF. The analytical results given in Table 1 agree with the suggested formula of complexes. Elemental analysis, FT-IR, ${ }^{1} \mathrm{H},{ }^{13} \mathrm{C}, 2 \mathrm{D}$ HMQC NMR, TGA/DSC, and UV-Visible spectroscopy were used to characterize the complexes. The elemental analyses indicate 3: 1 (ligand to metal) stoichiometry. The lower molar conductance values of the complexes in DMSO at $10^{-3} \mathrm{M}$ concentration suggest their nonelectrolytic nature and are given in Table 1.

3.1. IR Spectral Studies. The characteristic IR bands of HL and $\operatorname{Ln}(\mathrm{III})$ complexes are compiled in Table 2. In the IR spectrum of HL, the broad band observed at $3290 \mathrm{~cm}^{-1}$ was assigned to $v(\mathrm{OH})$ group of carboxylic acid. The appearance of this frequency at a slightly lower wave number is due to the involvement of $\mathrm{OH}$ group in intermolecular hydrogen bonding with oxygen atom of amide $v(\mathrm{C}=\mathrm{O})$ functional group [21]. The HL shows a very strong absorption band at $1736 \mathrm{~cm}^{-1}$ assigned to the $v(\mathrm{C}=\mathrm{O})$ of the carboxylic acid. The bands at $1659 \mathrm{~cm}^{-1}$ and $1609 \mathrm{~cm}^{-1}$ were assigned to amide $v(\mathrm{C}=\mathrm{O})$ and $v(\mathrm{C}=\mathrm{N})$, respectively.

The absence of band due to carboxylic $\mathrm{OH}$ group in the spectra of all lanthanide (III) complexes suggests the coordination to the metal ion via deprotonation. The band due to $v(\mathrm{C}=\mathrm{O})$ of carboxylic acid of HL was absent in all the lanthanide(III) complexes, indicating the participation of carbonyl oxygen in coordination to the metal ion [2224]. Whereas the two new characteristic bands appeared on complexation in the ranges of $1590-1562 \mathrm{~cm}^{-1}$ and $1372-1346 \mathrm{~cm}^{-1}$ were assigned to asymmetric and symmetric stretching frequencies of carboxylate ion, respectively. The difference between $v_{\text {asy }}\left(\mathrm{COO}^{-}\right)$and $v_{\text {sy }}\left(\mathrm{COO}^{-}\right)$frequencies in all complexes were found to be less than the difference observed in the sodium salt of HL. This implies that carboxylic acid group of HL has coordinated to metal ion in 
TABLE 1: Elemental analysis and molar conductivity measurements.

\begin{tabular}{|c|c|c|c|c|c|c|}
\hline \multirow{2}{*}{ Compounds } & \multirow{2}{*}{ Color } & \multicolumn{4}{|c|}{ Calculated (found) ${ }^{*}$} & \multirow{2}{*}{ Molar conductance ${ }^{* *}$} \\
\hline & & $\mathrm{C}$ & $\mathrm{H}$ & $\mathrm{N}$ & M & \\
\hline HL & White & $51.40(51.42)$ & $3.55(3.56)$ & $7.05(6.98)$ & - & - \\
\hline$\left[\mathrm{La}(\mathrm{L})_{3} \cdot 2 \mathrm{H}_{2} \mathrm{O}\right]$ & Yellow & $44.82(44.81)$ & $3.39(3.39)$ & $6.15(6.13)$ & $10.16(10.56)$ & 5.2 \\
\hline$\left[\operatorname{Pr}(\mathrm{L})_{3} \cdot 2 \mathrm{H}_{2} \mathrm{O}\right]$ & Yellow & $44.76(44.75)$ & $3.39(3.40)$ & $6.14(6.13)$ & $10.30(10.35)$ & 7.8 \\
\hline$\left[\mathrm{Nd}(\mathrm{L})_{3} \cdot 3 \mathrm{H}_{2} \mathrm{O}\right]$ & Light pink & $44.17(44.68)$ & $3.27(3.26)$ & $6.06(6.10)$ & $10.40(11.03)$ & 6.3 \\
\hline$\left[\mathrm{Sm}(\mathrm{L})_{3} \cdot 2 \mathrm{H}_{2} \mathrm{O}\right]$ & Yellow & $44.45(44.42)$ & $3.36(3.37)$ & $6.10(6.11)$ & $10.91(11.12)$ & 9.8 \\
\hline$\left[\mathrm{Eu}(\mathrm{L})_{3} \cdot 2 \mathrm{H}_{2} \mathrm{O}\right]$ & Yellow & $44.40(44.43)$ & $3.36(3.35)$ & $6.09(6.10)$ & $11.01(10.08)$ & 7.1 \\
\hline$\left[\mathrm{Gd}(\mathrm{L})_{3} \cdot 3 \mathrm{H}_{2} \mathrm{O}\right]$ & Off white & $43.76(43.69)$ & $3.24(3.26)$ & $6.00(6.03)$ & $11.23(11.56)$ & 4.6 \\
\hline$\left[\mathrm{Dy}(\mathrm{L})_{3} \cdot 3 \mathrm{H}_{2} \mathrm{O}\right]$ & Yellow & $43.59(43.55)$ & $3.23(3.22)$ & $5.98(6.05)$ & $11.56(12.05)$ & 8.5 \\
\hline$\left[\mathrm{Y}(\mathrm{L})_{3} \cdot 2 \mathrm{H}_{2} \mathrm{O}\right]$ & Yellow & $46.53(46.31)$ & $3.52(3.53)$ & $6.38(6.39)$ & $06.75(06.86)$ & 4.5 \\
\hline
\end{tabular}

${ }^{*}$ The values in the parenthesis are calculated ones.

${ }^{* *} \mathrm{Ohm}^{-1} \mathrm{~cm}^{2} \mathrm{~mol}^{-1}$.

TABLE 2: FT-IR analysis of $\mathrm{HL}$ and $\left[\mathrm{Ln}(\mathrm{L})_{3} \cdot n \mathrm{H}_{2} \mathrm{O}\right]$.

\begin{tabular}{|c|c|c|c|c|c|c|c|c|}
\hline Compounds & $v(\mathrm{OH})$ & $\begin{array}{l}v(\mathrm{CO}) \\
\text { (amide) }\end{array}$ & $\begin{array}{c}v(\mathrm{CO}) \\
\text { (carboxylic) }\end{array}$ & $v_{\text {asy }}\left(\mathrm{COO}^{-}\right)$ & $v_{s}\left(\mathrm{COO}^{-}\right)$ & $\Delta n\left(v_{\text {asy }}-v_{s}\right)$ & $v(\mathrm{C}=\mathrm{N})$ & $v\left(\mathrm{H}_{2} \mathrm{O}\right)$ \\
\hline $\mathrm{HL}$ & 3290 & 1659 & 1736 & n.o ${ }^{*}$ & n.o & n.o & 1609 & n.o \\
\hline $\mathrm{NaL}$ & n.o & 1692 & n.o & 1603 & 1377 & 226 & 1611 & 3460 \\
\hline$\left[\mathrm{La}(\mathrm{L})_{3} \cdot 2 \mathrm{H}_{2} \mathrm{O}\right]$ & n.o & 1692 & n.o & 1590 & 1372 & 218 & 1609 & 3448 \\
\hline$\left[\operatorname{Pr}(\mathrm{L})_{3} \cdot 2 \mathrm{H}_{2} \mathrm{O}\right]$ & n.o & 1690 & n.o & 1564 & 1348 & 216 & 1613 & 3450 \\
\hline$\left[\mathrm{Nd}(\mathrm{L})_{3} \cdot 3 \mathrm{H}_{2} \mathrm{O}\right]$ & n.o & 1695 & n.o & 1574 & 1362 & 212 & 1612 & 3435 \\
\hline$\left[\mathrm{Sm}(\mathrm{L})_{3} \cdot 2 \mathrm{H}_{2} \mathrm{O}\right]$ & n.o & 1689 & n.o & 1574 & 1358 & 216 & 1608 & 3448 \\
\hline$\left[\mathrm{Eu}(\mathrm{L})_{3} \cdot 2 \mathrm{H}_{2} \mathrm{O}\right]$ & n.o & 1691 & n.o & 1581 & 1370 & 211 & 1610 & 3450 \\
\hline$\left[\mathrm{Gd}(\mathrm{L})_{3} \cdot 3 \mathrm{H}_{2} \mathrm{O}\right]$ & n.o & 1692 & n.o & 1573 & 1355 & 218 & 1613 & 3421 \\
\hline$\left[\mathrm{Dy}(\mathrm{L})_{3} \cdot 3 \mathrm{H}_{2} \mathrm{O}\right]$ & n.o & 1696 & n.o & 1562 & 1346 & 216 & 1608 & 3425 \\
\hline$\left[\mathrm{Y}(\mathrm{L})_{3} \cdot 2 \mathrm{H}_{2} \mathrm{O}\right]$ & n.o & 1693 & n.o & 1581 & 1368 & 213 & 1613 & 3448 \\
\hline
\end{tabular}

*n.o: not observed.

bidentate fashion via deprotonation as suggested by Deacon [22, 25-28].

A strong band at $1659 \mathrm{~cm}^{-1}$ in the spectrum of uncoordinated ligand is assigned to amide $v(\mathrm{C}=\mathrm{O})$ and has shifted to higher wave number in all complexes. This increase in frequency of amide $v(\mathrm{C}=\mathrm{O})$ functional group may be due to the breaking of hydrogen bond present in $\mathrm{HL}$ on complexation. Azomethine nitrogen $v(\mathrm{C}=\mathrm{N})$ has not suffered any change on complexation indicating its noninvolvement in coordination.

The presence of a broad band in the region $3460-3421 \mathrm{~cm}^{-1}$ was attributed to the $v(\mathrm{O}-\mathrm{H})$ of coordinated water molecules in all complexes [29]. This was further confirmed by the appearance of a weak nonligand band in the region $831-856 \mathrm{~cm}^{-1}$, assignable to rocking mode of coordinated water molecule [30]. The presence of coordinated water molecules was further confirmed by thermal studies.

\subsection{NMR Spectroscopy}

3.2.1. NMR Spectral Studies of HL. The NMR spectrum of HL shows double set of signals for all the protons and carbons due to its existence in $\mathrm{E}$ and $\mathrm{Z}$ isomeric forms arising due to the restricted rotation along the $(-\mathrm{HC}=\mathrm{N}-)$ functional group. From the ${ }^{1} \mathrm{H}$ NMR data, the ratio of $\mathrm{E}$ and $\mathrm{Z}$ isomers was approximately found to be $70: 30$ with $E$ isomer as the predominant one over $\mathrm{Z}$ isomer.

The isomeric structure of $\mathrm{HL}$ and its numbering are presented in Figure 1. The ${ }^{1} \mathrm{H}$ NMR spectrum is given in Figure 2. The detailed assignments for both the isomers are given in the experimental section. The singlet observed at $13.16 \mathrm{ppm}$ was assigned to $\mathrm{OH}$ proton of carboxylic acid. Two singlets observed at 11.72 and $11.80 \mathrm{ppm}$ were assigned to amide $\mathrm{NH}$ and $\mathrm{NH}^{\prime}$ protons, respectively. The $\mathrm{C} 11 \mathrm{H}$ and $\mathrm{C} 11^{\prime} \mathrm{H}$ protons present adjacent to carbonyl functional group were observed at 4.80 and $5.31 \mathrm{ppm}$, respectively. The $\mathrm{C} 2 \mathrm{H}$ and $\mathrm{C}^{\prime} \mathrm{H}$ protons present adjacent to carboxylic functional group were observed at 4.82 and $4.90 \mathrm{ppm}$, respectively. The azomethine protons $\mathrm{C} 9 \mathrm{H}$ and $\mathrm{C}^{\prime} \mathrm{H}$ were observed at 8.42 and $8.65 \mathrm{ppm}$, respectively [31]. The aromatic protons were observed between 6.99-7.90 ppm.

${ }^{1} \mathrm{H}-\mathrm{NMR}$ analysis is supported by the ${ }^{13} \mathrm{C}$ and DEPT NMR spectral analysis for the confirmation of $\mathrm{E}$ and $\mathrm{Z}$ isomerism in $\mathrm{HL}$. The ${ }^{13} \mathrm{C}$ spectrum of $\mathrm{HL}$ is given in Figure 3 and its DEPT NMR is presented at Figure 4. DEPT NMR at $135^{\circ}$ pulse assisted the assignment of ${ }^{13} \mathrm{C}$ 


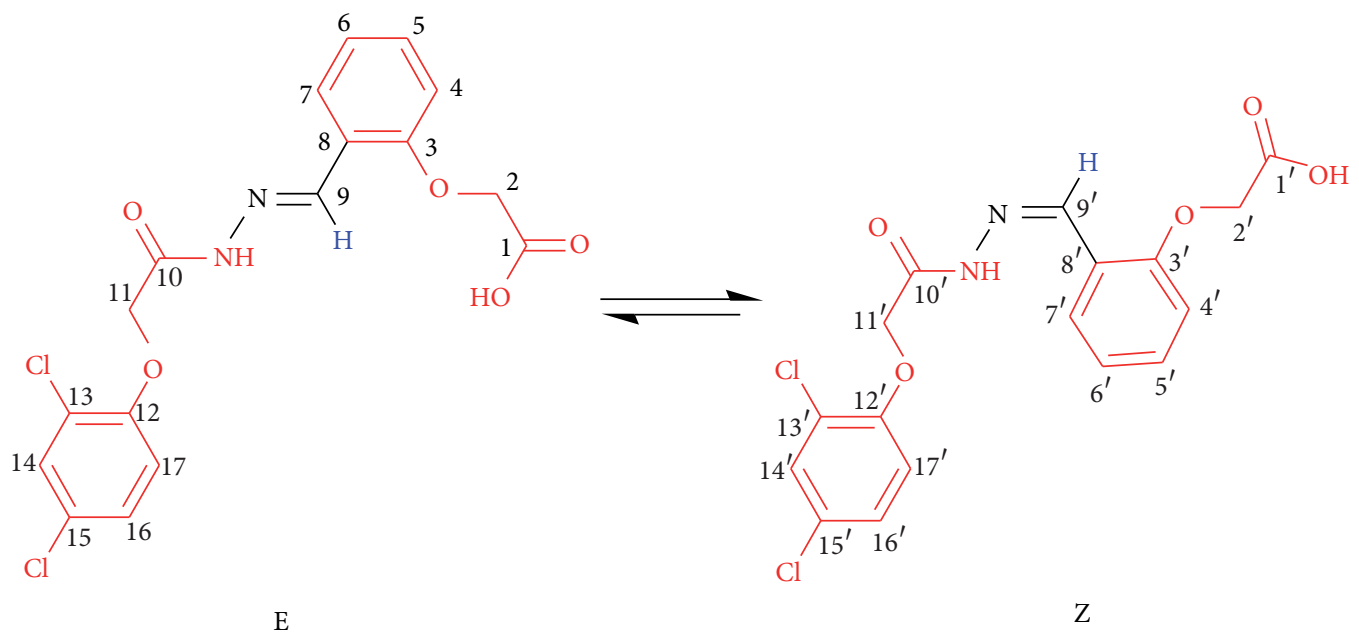

Figure 1: Isomeric structures of HL.

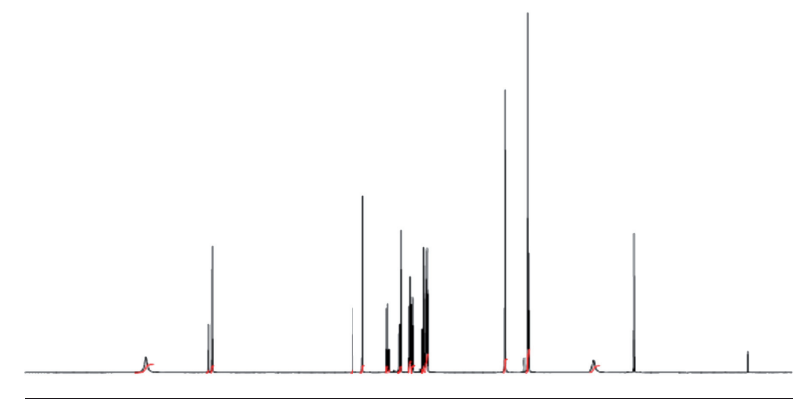

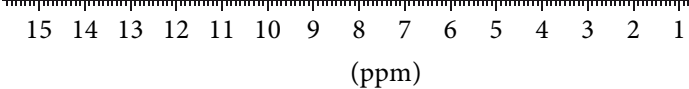

FIgURE 2: ${ }^{1} \mathrm{H}$ NMR spectrum of HL.

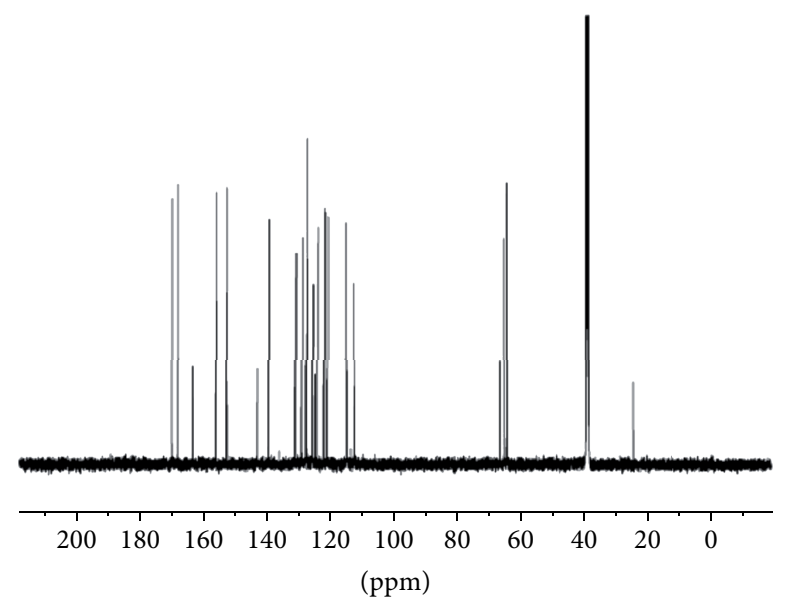

Figure 3: ${ }^{13} \mathrm{C}$ NMR spectrum of HL.

resonance. The primary and tertiary carbons phased up and secondary carbons phased down, while signals for quaternary carbons and other carbons with no attached protons found absent in DEPT NMR were observed at 169.88 and $169.94 \mathrm{ppm}$, respectively. These quaternary carbons were absent in DEPT-135 NMR spectrum. Carbon signals at
$116.15,117.13$ (C8/C8'), 122.02, 122.20 (C13/C13'), 125.58, $125.77\left(\mathrm{C} 15 / \mathrm{C}^{\prime} 5^{\prime}\right), 152.54,152.73\left(\mathrm{C} 12 / \mathrm{C} 12^{\prime}\right), 163.28,168.12$ $\left(\mathrm{C} 10 / \mathrm{C} 10^{\prime}\right), 156.08,156.20\left(\mathrm{C} 3 / \mathrm{C}^{\prime}\right)$, and $169.88,169.94$ $\left(\mathrm{C} 1 / \mathrm{Cl}^{\prime}\right)$ were absent in DEPT-135 NMR spectrum which confirms their assignment for quaternary carbons. In ${ }^{13} \mathrm{C}$ NMR spectrum, the methyne carbons C9 and C9' were 


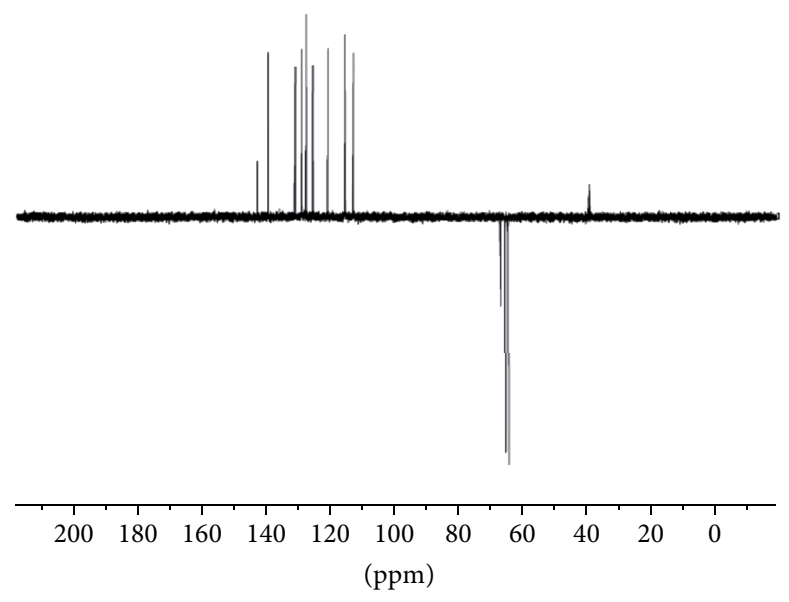

FIGURE 4: DEPT NMR spectrum of HL.

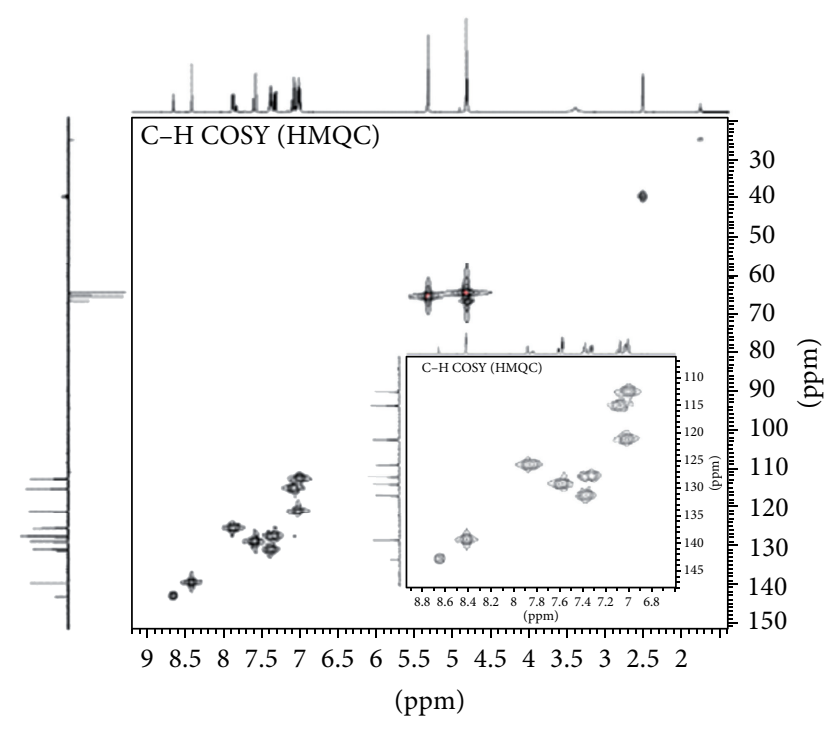

Figure 5: 2D HMQC NMR spectrum of HL.

resonated at 139.00 and $143.00 \mathrm{ppm}$, respectively, and were phased up in the DEPT-135 NMR spectrum. The signals for $\mathrm{CH}$ carbons in DEPT NMR were observed at 112.47, 112.84 (C4/C4'), 114.97, 115.12 (C17/C17'), 121.01, 121.03 (C16/C16'), 124.38, 124.94 (C6/C6'), 127.75, 127.96 (C5/C5 $\left.{ }^{\prime}\right), 129.12,129.30$ (C7/C7'), 131.15, $131.44\left(\mathrm{C} 14 / \mathrm{C} 14^{\prime}\right)$ and $139.00,143.00\left(\mathrm{C} 9 / \mathrm{C}^{\prime}\right)$ phased up in spectrum are in accordance with ${ }^{13} \mathrm{C}$ NMR spectral assignments. The $\mathrm{C} 11$ and $\mathrm{C} 11^{\prime}$ carbons were observed at 64.67 and $66.91 \mathrm{ppm}$, respectively. The signals for C2 and C2' were observed at 64.62 and 64.75 ppm, respectively. The signals for methylene carbons $\mathrm{C} 11, \mathrm{C} 11^{\prime}, \mathrm{C} 2$, and $\mathrm{C}^{\prime}$ ' were phased down in the DEPT NMR spectrum. In ${ }^{13} \mathrm{C}$ NMR the resonances for aromatic carbons were observed in the range of 112.47-131.90 ppm.

All assignments were further studied by $2 \mathrm{D} \mathrm{HMQC} \mathrm{NMR}$ spectral analysis and the spectrum is given in Figure 5. The spectrum correlates the directly bonded ${ }^{1} \mathrm{H}$ and ${ }^{13} \mathrm{C}$ NMR resonances. The resonance observed in ${ }^{1} \mathrm{H}$ NMR spectrum

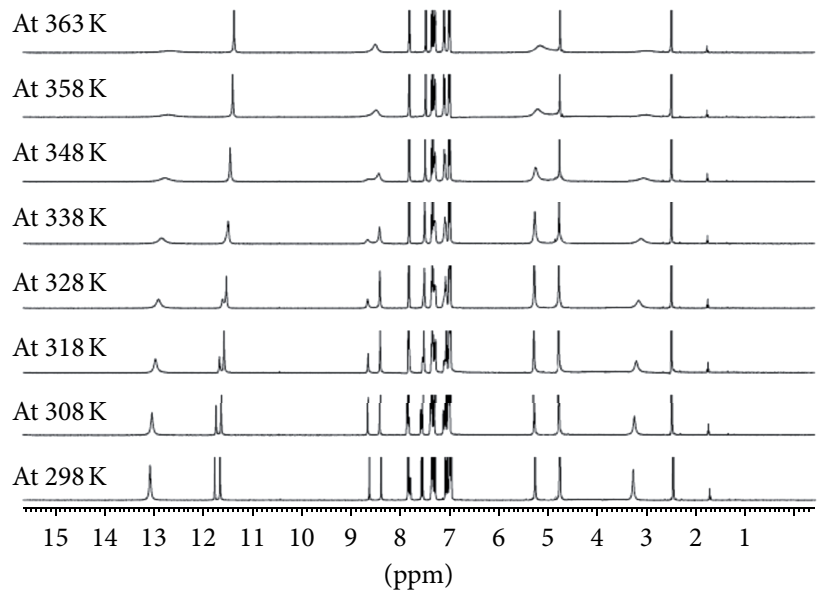

FIGURE 6: Variable temperature ${ }^{1}$ HNMR spectra of HL.

at $13.16 \mathrm{ppm}, 11.72$, and 11.80 were assigned to $\mathrm{OH}, \mathrm{NH}$, and $\mathrm{NH}^{\prime}$ protons, respectively, which are devoid of any attached carbon signals, and were confirmed in 2D HMQC NMR spectral analysis.

Isomeric Investigation of HL by Variable Temperature NMR. It is well known that, in case of $\mathrm{E}$ and $\mathrm{Z}$ isomers, as the temperature increases, interconversion of two isomers also increases due to the increase in rotation along $\mathrm{C} 8$ C9 bond and one of them will become predominant over the other isomer at higher temperature [32]. To study the interconvertion phenomenon, variable temperature ${ }^{1} \mathrm{H}$ NMR analyses were undertaken [33] in the temperature range from $298 \mathrm{~K}$ to $363 \mathrm{~K}$ and the spectrum is given in Figure 6. At room temperature $(298 \mathrm{~K})$, the resonances for both $\mathrm{E}$ and $\mathrm{Z}$ isomers are well distinguishable. As the temperature is increased $(308 \mathrm{~K})$, the intensities of signals assigned to $\mathrm{Z}$ isomer have comparatively decreased. At $338 \mathrm{~K}$, signals were reduced to more than half of their original intensity. It implies that increase in temperature causes the interconvertion of two isomers. At $348 \mathrm{~K}$, the signals observed at $8.65 \mathrm{ppm}\left(\mathrm{C}^{\prime} H\right)$,

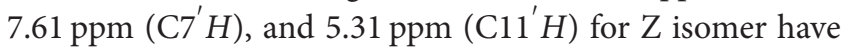




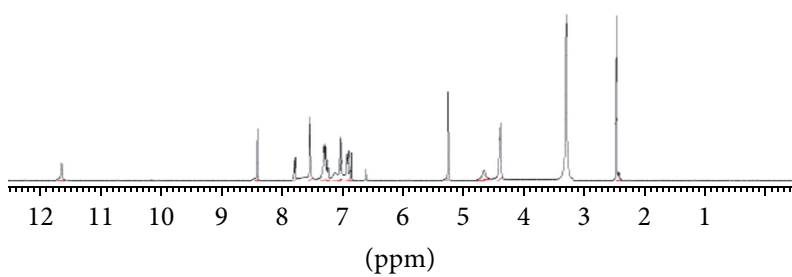

Figure $7:{ }^{1} \mathrm{H}$ NMR spectrum of $\left[\mathrm{La}(\mathrm{L})_{3} \cdot 2 \mathrm{H}_{2} \mathrm{O}\right]$.

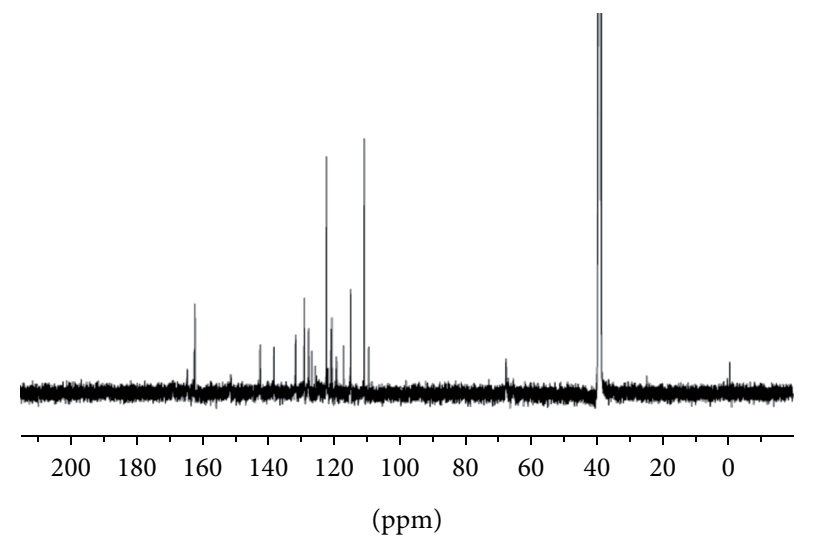

Figure $8:{ }^{13} \mathrm{C}$ NMR spectrum of $\left[\mathrm{La}(\mathrm{L})_{3} \cdot 2 \mathrm{H}_{2} \mathrm{O}\right]$.

completely disappeared and at the same time, the remaining signals have also suffered a significant decrease in their intensities. At $363 \mathrm{~K}$, almost a single set of signals was observed.

3.2.2. NMR Spectral Studies of Lanthanum(III) Complex. In the spectrum of the lanthanum(III) complex shown at Figure 7 , only one set of signals was observed for each proton and carbon, indicating the presence of HL in only one form. The resonance at $13.16 \mathrm{ppm}$ assigned to carboxylic acid proton in HL has completely disappeared in lanthanum(III) complex indicating the coordination of HL through carboxylic group via deprotonation [22]. The carboxylic acid coordination was supported by downfield shift of $\mathrm{CH}_{2}$ protons adjacent to carboxylic acid. The $\mathrm{C} 11 \mathrm{H}, \mathrm{C} 9 \mathrm{H}$, and $\mathrm{NH}$ signals observed at $4.80,8.42$, and $11.72 \mathrm{ppm}$, respectively in the spectrum of HL have now been observed at 4.70, 8.41, and $11.64 \mathrm{ppm}$, respectively, in the NMR spectrum of lanthanum(III) complex. This observation confirms that the carbonyl oxygen and azomethine nitrogen were not involved in coordination. Significant changes were not observed in the chemical shift values of aromatic protons after complexation.

${ }^{13} \mathrm{C}$ NMR spectrum further supports the mode of coordination of HL. The spectrum is given in Figure 8. The carbonyl carbon $\mathrm{C} 1$ of carboxylic acid observed at $169.88 \mathrm{ppm}$ in HL has shifted downfield to $176.46 \mathrm{ppm}$ in the complex suggesting the involvement of carboxylic acid in coordination [22]. It was further supported by downfield shift of $\mathrm{C} 2$ carbon resonance from $64.62 \mathrm{ppm}$ to $67.55 \mathrm{ppm}$ on complexation. Small change was observed in the chemical shift values of carbonyl carbon C10 on complexation. This

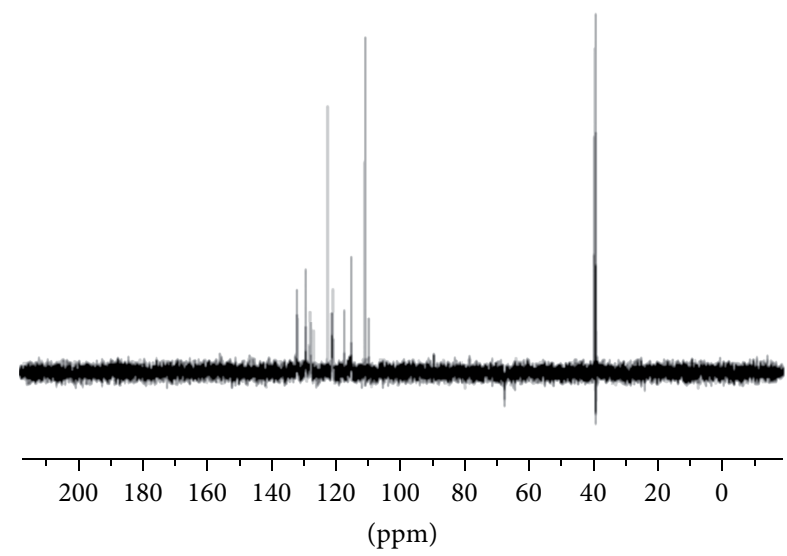

FIGURE 9: DEPT NMR spectrum of $\left[\mathrm{La}(\mathrm{L})_{3} \cdot 2 \mathrm{H}_{2} \mathrm{O}\right]$.

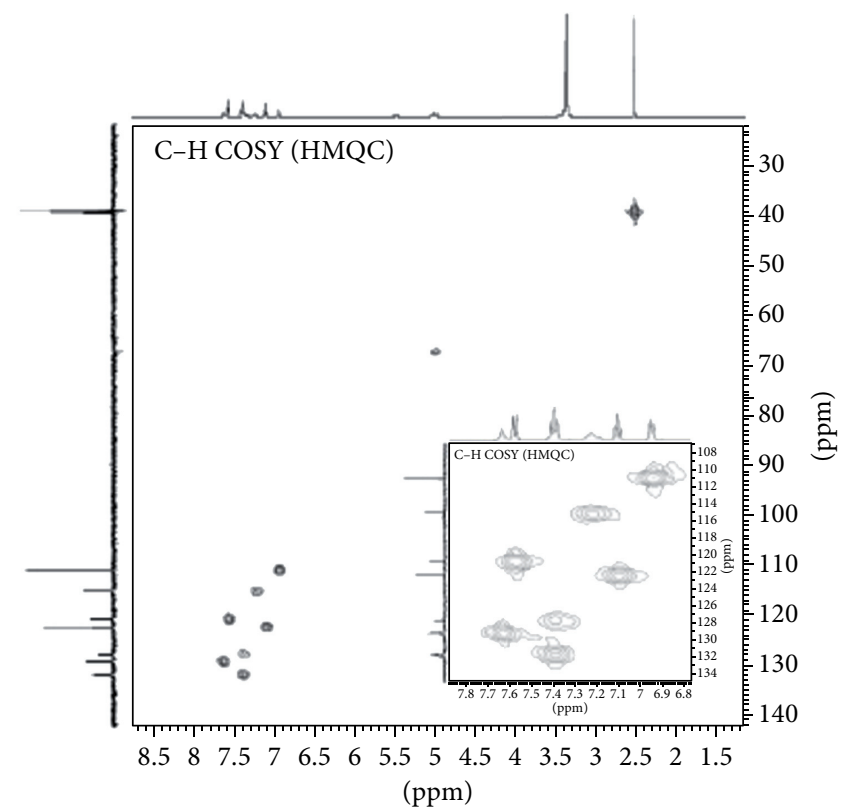

Figure 10: 2D HMQC spectrum of [La $\left.(\mathrm{L})_{3} \cdot 2 \mathrm{H}_{2} \mathrm{O}\right]$.

indicates breakdown of hydrogen bond after complexation [34].

The ${ }^{13} \mathrm{C}$ NMR spectral assignment was further confirmed by DEPT spectral analysis and is presented in Figure 9. The $\mathrm{CH}_{2}$ carbons observed at $66.91 \mathrm{ppm}$ assigned to $\mathrm{C} 11$ carbon and $67.55 \mathrm{ppm}$ to $\mathrm{C} 2$ carbon were found phased down in the spectrum. The signals at 112.47 (C4), 115.28 (C17), 122.25 (C16), 126.92 (C6), 127.96 (C5), 129.12 (C7), 131.90 (C14), and 138.50 (C9) are due to $\mathrm{CH}$ carbons and were found phased up in the spectrum. The resonances at 117.13 (C8), 122.13 (C13), 124.30 (C15), 153.00 (C12), 156.08, (C3), $164.30(\mathrm{C} 10)$, and $176.46(\mathrm{C} 1)$ are the quaternary carbons, which were absent in DEPT spectrum.

The assignments were further studied by $2 \mathrm{D}$ HMQC NMR spectrum. The spectrum is given in Figure 10. The resonance observed at $11.64 \mathrm{ppm}$ was devoid of any attached carbon signal confirming their assignment to $\mathrm{NH}$ proton. 
TABLE 3: Thermal decomposition data of $\left[\mathrm{Ln}(\mathrm{L})_{3} \cdot n \mathrm{H}_{2} \mathrm{O}\right]$.

\begin{tabular}{|c|c|c|c|c|}
\hline \multirow{2}{*}{ Complex } & \multirow{2}{*}{ Temperature range $\left({ }^{\circ} \mathrm{C}\right)$} & \multicolumn{2}{|c|}{ Weight loss in \% } & \multirow{2}{*}{ Molecule decomposed } \\
\hline & & Found & Calculated & \\
\hline \multirow{3}{*}[\mathrm{La}(\mathrm{L})_{3}\cdot2\mathrm{H}_{2}\mathrm{O}]{} & $137.03-148.31$ & 2.60 & 2.64 & $2 \mathrm{H}_{2} \mathrm{O}$ \\
\hline & $378.71-488.46$ & 87.38 & 87.35 & $3 \mathrm{~L}$ \\
\hline & $488.46-1000$ & 10.02 & 10.01 & Residue \\
\hline \multirow{3}{*}[\operatorname{Pr}(\mathrm{L})_{3}\cdot2\mathrm{H}_{2}\mathrm{O}]{} & $152.03-173$ & 2.66 & 2.64 & $2 \mathrm{H}_{2} \mathrm{O}$ \\
\hline & $375.71-510.60$ & 87.35 & 87.23 & $3 \mathrm{~L}$ \\
\hline & $510.60-1000$ & 9.99 & 10.13 & Residue \\
\hline \multirow{3}{*}[\mathrm{Nd}(\mathrm{L})_{3}\cdot3\mathrm{H}_{2}\mathrm{O}]{} & $155.33-181.03$ & 3.90 & 3.91 & $3 \mathrm{H}_{2} \mathrm{O}$ \\
\hline & $376.71-485.32$ & 86.13 & 86.03 & $3 \mathrm{~L}$ \\
\hline & $485.32-1000$ & 9.97 & 10.06 & Residue \\
\hline \multirow{3}{*}[\mathrm{Sm}(\mathrm{L})_{3}\cdot2\mathrm{H}_{2}\mathrm{O}]{} & $142.03-170.02$ & 2.59 & 2.62 & $2 \mathrm{H}_{2} \mathrm{O}$ \\
\hline & $365.71-483.40$ & 86.50 & 86.53 & $3 \mathrm{~L}$ \\
\hline & $483.40-1000$ & 10.91 & 10.85 & Residue \\
\hline \multirow{3}{*}[\mathrm{Eu}(\mathrm{L})_{3}\cdot2\mathrm{H}_{2}\mathrm{O}]{} & $162.51-210.02$ & 2.65 & 2.62 & $2 \mathrm{H}_{2} \mathrm{O}$ \\
\hline & $370.71-484$ & 86.40 & 86.46 & $3 \mathrm{~L}$ \\
\hline & 484-1000 & 10.95 & 10.92 & Residue \\
\hline \multirow{3}{*}[\mathrm{Gd}(\mathrm{L})_{3}\cdot3\mathrm{H}_{2}\mathrm{O}]{} & $168.20-203.72$ & 3.82 & 3.86 & $3 \mathrm{H}_{2} \mathrm{O}$ \\
\hline & $369-477$ & 85.11 & 85.14 & $3 \mathrm{~L}$ \\
\hline & 477-1000 & 11.07 & 11.10 & Residue \\
\hline \multirow{3}{*}[\mathrm{Dy}(\mathrm{L})_{3}\cdot3\mathrm{H}_{2}\mathrm{O}]{} & $156.03-183.66$ & 3.87 & 3.84 & $3 \mathrm{H}_{2} \mathrm{O}$ \\
\hline & $386.01-495.48$ & 84.72 & 84.68 & $3 \mathrm{~L}$ \\
\hline & $495.48-1000$ & 11.41 & 11.48 & Residue \\
\hline \multirow{3}{*}[\mathrm{Y}(\mathrm{L})_{3}\cdot2\mathrm{H}_{2}\mathrm{O}]{} & $156-173$ & 2.72 & 2.71 & $2 \mathrm{H}_{2} \mathrm{O}$ \\
\hline & $374.07-488$ & 89.55 & 89.59 & $3 \mathrm{~L}$ \\
\hline & $488-1000$ & 7.73 & 07.70 & Residue \\
\hline
\end{tabular}

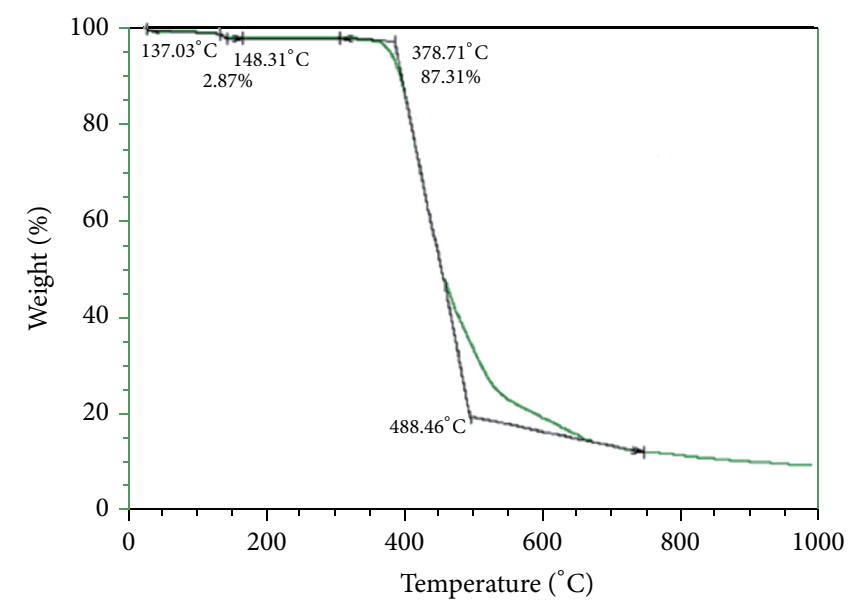

FIgURE 11: Thermogram of [La $\left.(\mathrm{L})_{3} \cdot 2 \mathrm{H}_{2} \mathrm{O}\right]$.

3.3. Thermal Analysis. The thermal stability data of $\operatorname{Ln}(\mathrm{III})$ complexes (where, Ln = La, Pr, Nd, Sm, Eu, Gd, Dy, Y) are compiled in Table 3. As a representative, the thermogram of $\mathrm{La}$ (III) complex is shown in Figure 11. Under nitrogen atmosphere, the complex undergoes a three-step decomposition.
The first weight loss found between $137.03^{\circ} \mathrm{C}$ to $210.02^{\circ} \mathrm{C}$ corresponds to the loss of coordinated water molecules. In $\mathrm{La}(\mathrm{III}), \operatorname{Pr}(\mathrm{III}), \mathrm{Sm}(\mathrm{III}), \mathrm{Eu}(\mathrm{III})$, and Y(III) complexes, the weight loss corresponds to two coordinated water molecules while in $\mathrm{Nd}(\mathrm{III}), \mathrm{Gd}(\mathrm{III})$, and Dy(III) complexes, the weight 


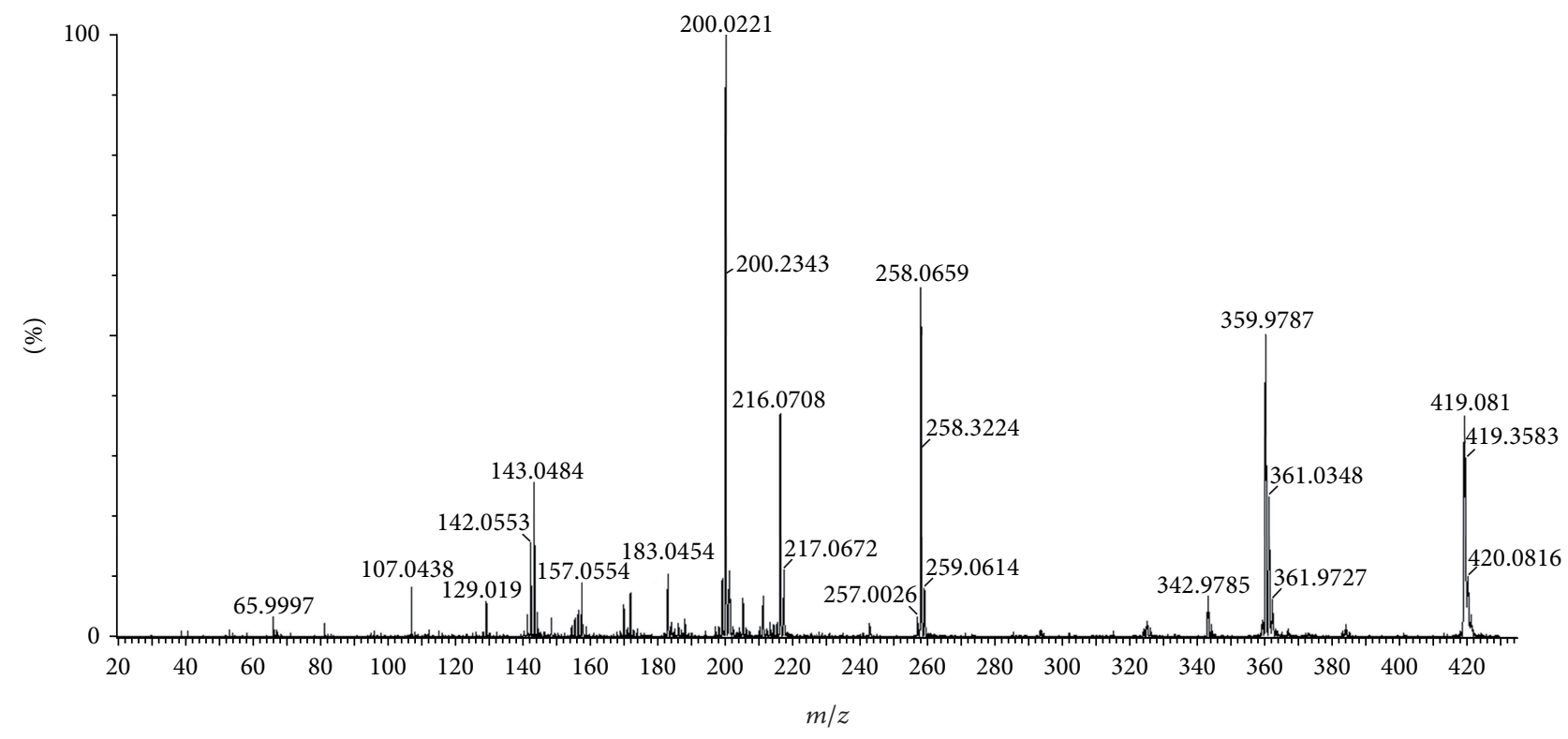

FIGURE 12: Mass spectrum of HL.

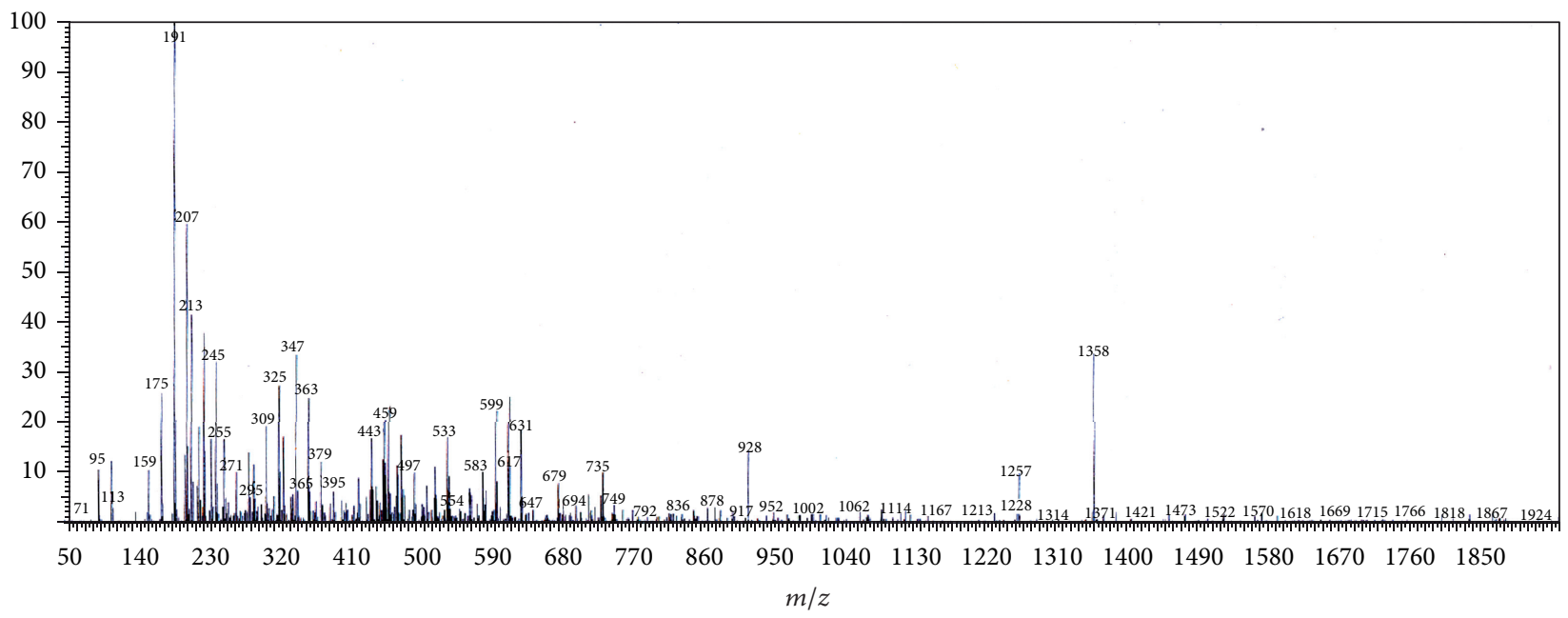

Figure 13: ESI mass spectrum of [La $\left.(\mathrm{L})_{3} \cdot 2 \mathrm{H}_{2} \mathrm{O}\right]$.

loss corresponds to three coordinated water molecules. The second weight loss between $365.71^{\circ} \mathrm{C}$ to $510.60^{\circ} \mathrm{C}$ is due to the loss of three ligand molecules in all complexes. Third step weight losses correspond to the formation of residue. The observed weight losses match with calculated values for the metal content [35].

3.4. ESI Mass Analysis. The ESI mass spectrum of $\mathrm{HL}$ is given in Figure 12. The molecular ion peak $\mathrm{m} / z=419$ corresponds to sodium adduct of HL. The mass spectra of complexes are in good agreement with the expected molecular weights. All the molecular weights are adducting with the proton. The representative spectrum of lanthanum complex is given in Figure 13. In the given mass spectrum of $\mathrm{La}$ (III) complex, the molecular ion peak $m / z=1358$ due to $[\mathrm{M}-\mathrm{H}]^{+}$ ion.
3.5. Electronic Spectra. The electronic spectra of HL and its lanthanide(III) complexes were recorded in DMSO at room temperature. The two absorption maxima at $278 \mathrm{~nm}$ and $318 \mathrm{~nm}$ in the spectrum of HL were assigned to $\pi \rightarrow \pi^{*}$ transitions of carbonyl oxygen and azomethine $(-\mathrm{C}=\mathrm{N}-)$ moiety. No significant changes were observed in these bands on complexation.

3.6. Emission Spectra. The emission spectrum of $\mathrm{Eu}(\mathrm{III})$ complex was recorded in the solid state in the range of $300-700 \mathrm{~nm}$ by selective excitation wavelength at $318 \mathrm{~nm}$. The three emission peaks observed were at 578,592 , and $612 \mathrm{~nm}$. The bands at 578,592, and $612 \mathrm{~nm}$ were assigned to ${ }^{5} \mathrm{D}_{0} \rightarrow{ }^{7} \mathrm{~F}_{0},{ }^{5} \mathrm{D}_{0} \rightarrow{ }^{7} \mathrm{~F}_{1}$, and ${ }^{5} \mathrm{D}_{0} \rightarrow{ }^{7} \mathrm{~F}_{2}$, respectively. The intensity of $612 \mathrm{~nm}$ band was found to be more intense than other two bands $[36,37]$. 


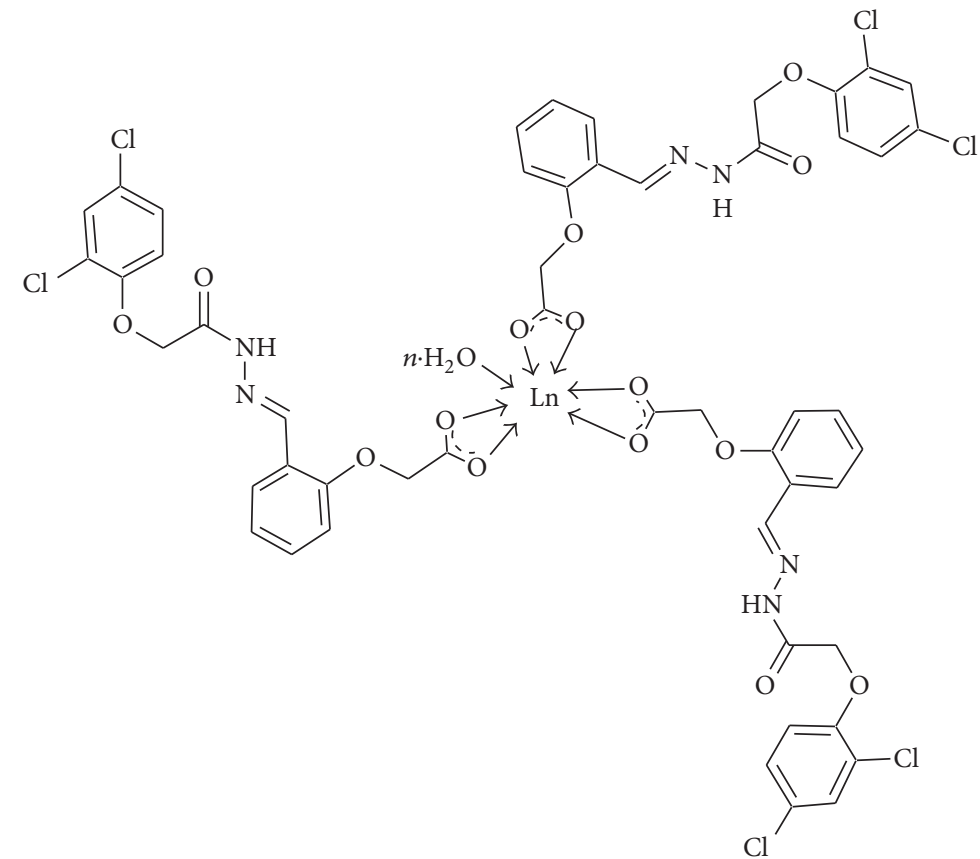

Ln = La(III), Pr(III), Nd(III), Sm(III), Eu(III), Gd(III), Dy(III), Y(III)

$n=2$ for $\mathrm{La}(\mathrm{III}), \operatorname{Pr}(\mathrm{III}), \mathrm{Sm}$ (III), $\mathrm{Eu}(\mathrm{III}), \mathrm{Y}(\mathrm{III})$

$n=3$ for Nd(III), Gd(III), Dy(III)

FIgURE 14: Tentative structure of $\left[\mathrm{Ln}(\mathrm{L}) 3 \cdot n \mathrm{H}_{2} \mathrm{O}\right]$.

TABle 4: Plant growth activity on wheat seeds.

\begin{tabular}{|c|c|c|c|c|}
\hline Sl. no. & Treatments & Germination percentage & Root length $(\mathrm{cm})$ & Shoot length $(\mathrm{cm})$ \\
\hline \multicolumn{5}{|c|}{$1 \times 10^{-5} \mathrm{M}$} \\
\hline 1 & Group $1^{* *}$ & 100 & $18.60 \pm 1.89 \mathrm{fghi}$ & $16.14 \pm 0.56 b c^{*}$ \\
\hline 2 & Group 2 & 97.60 & $18.08 \pm 1.95 \mathrm{ghi}$ & $16.03 \pm 0.53 \mathrm{bc}$ \\
\hline 3 & Group 3 & 80.00 & $17.87 \pm 2.88 \mathrm{hi}$ & $15.55 \pm 1.67 c$ \\
\hline 4 & Group 4 & 85.00 & $20.97 \pm 2.37 c d$ & $16.31 \pm 1.48 \mathrm{bc}$ \\
\hline 5 & Group 5 & 76.00 & $16.82 \pm 1.29 \mathrm{i}$ & $13.09 \pm 1.91 \mathrm{e}$ \\
\hline 6 & Group 6 & 80.50 & $14.77 \pm 0.92 \mathrm{j}$ & $13.56 \pm 2.47 \mathrm{de}$ \\
\hline \multicolumn{5}{|c|}{$1 \times 10^{-6} \mathrm{M}$} \\
\hline 1 & Group 1 & 98.50 & $18.04 \pm 0.92 \mathrm{ghi}$ & $16.55 \pm 2.03 \mathrm{bc}$ \\
\hline 2 & Group 2 & 98.00 & $17.91 \pm 2.63 \mathrm{hi}$ & $16.28 \pm 1.63 c$ \\
\hline 3 & Group 3 & 98.60 & $21.35 \pm 1.30 c$ & $17.06 \pm 2.22 \mathrm{bc}$ \\
\hline 4 & Group 4 & 98.00 & $20.05 \pm 2.14 \mathrm{cdefg}$ & $16.84 \pm 2.15 b c$ \\
\hline 5 & Group 5 & 100 & $25.70 \pm 1.25 b$ & $18.10 \pm 2.23 b$ \\
\hline 6 & Group 6 & 98.50 & $28.28 \pm 0.99 a$ & $20.06 \pm 1.22 \mathrm{a}$ \\
\hline \multicolumn{5}{|c|}{$1 \times 10^{-7} \mathrm{M}$} \\
\hline 1 & Group 1 & 100 & $18.90 \pm 2.51 \mathrm{efgh}$ & $15.98 \pm 2.04 \mathrm{bc}$ \\
\hline 2 & Group 2 & 99.00 & $18.82 \pm 3.08$ efghi & $16.17 \pm 2.94 \mathrm{bc}$ \\
\hline 3 & Group 3 & 98.00 & $19.32 \pm 0.73$ defgh & $15.27 \pm 2.52 \mathrm{~cd}$ \\
\hline 4 & Group 4 & 96.00 & $20.26 \pm 2.37 \mathrm{cdef}$ & $16.92 \pm 1.77 \mathrm{bc}$ \\
\hline 5 & Group 5 & 98.50 & $20.74 \pm 1.83 c d e$ & $16.48 \pm 3.17 \mathrm{bc}$ \\
\hline 6 & Group 6 & 98.00 & $21.78 \pm 2.63 c$ & $16.24 \pm 1.13 \mathrm{bc}$ \\
\hline
\end{tabular}

*Values are the mean of triplicates. Mean values followed by different letters are significantly different within a row or column at $5 \%$ probability level; that is, $\alpha=0.05(P<0.05)$ according to Duncan statistics.

${ }^{* *}$ Group 1: water, Group 2: DMSO and water mixture, Group 3: 2,4-D, Group 4: lanthanum nitrate, Group 5: HL, Group 6: La (III) complex. 


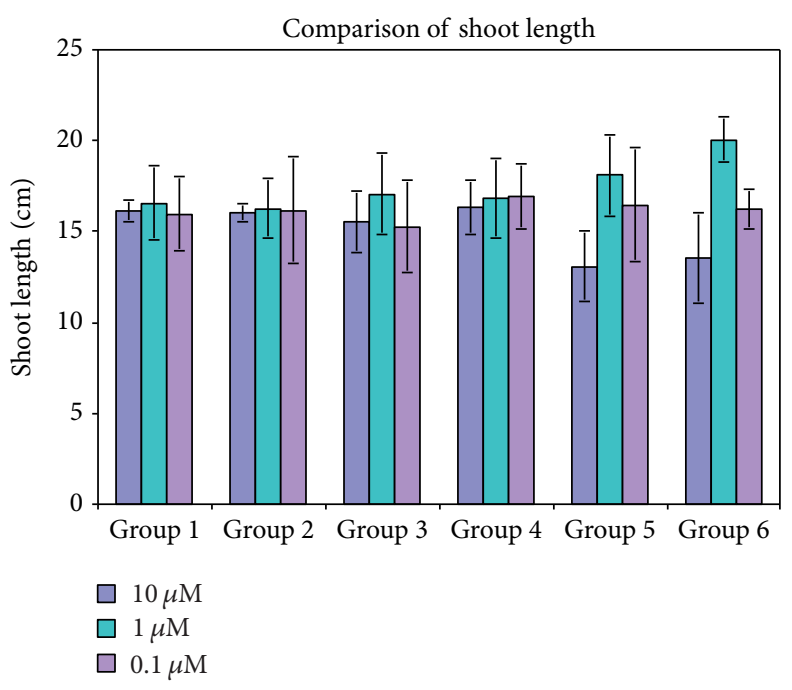

FIGURE 15: Comparison of shoot length Group $1=$ Water, Group $2=$ DMSO and Water mixture, Group 3=2,4-D, Group $4=$ Lanthanum nitrate, Group $5=\mathrm{HL}$, Group $6=\mathrm{La}(\mathrm{L})_{3} \cdot 2 \mathrm{H}_{2} \mathrm{O}$.

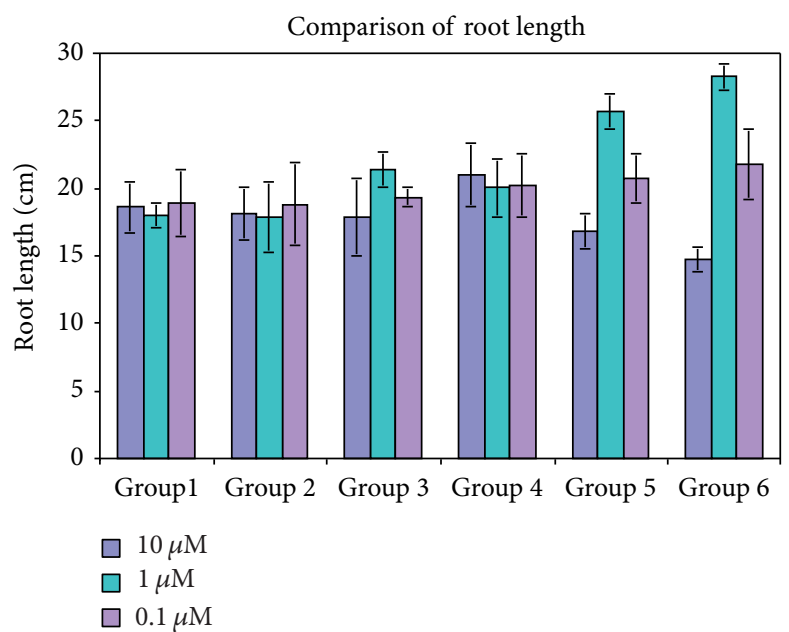

FIGURE 16: Comparison of root length. Group 1 = Water, Group 2 = DMSO and Water mixture, Group $3=2,4$-D, Group $4=$ Lanthanum nitrate, Group $5=\mathrm{HL}$, Group $6=\mathrm{La}(\mathrm{L})_{3} \cdot 2 \mathrm{H}_{2} \mathrm{O}$.

From the spectral and analytical data, the general molecular formula for complexes is given as $\left[\operatorname{Ln}(\mathrm{L})_{3} \cdot n \mathrm{H}_{2} \mathrm{O}\right]$. The tentative structure for the complexes is given in Figure 14.

3.7. Plant Growth Activity. The effect of $\mathrm{HL}$ and its $\mathrm{La}(\mathrm{III})$ complex at different concentrations in the growth of root and shoot of the germinated wheat seeds was analyzed with statistical analysis and data are compiled in Table 4 . Among the three concentrations used, that is, $1 \times 10^{-5}, 1 \times 10^{-6}$, and $1 \times$ $10^{-7} \mathrm{M}$, the growth of root and shoot is more at $1 \times 10^{-6} \mathrm{M}$ concentration. The growth activity exhibited by HL (Group 5) and $\mathrm{La}$ (III) complex (Group 6) is compared with that of control (Group 1), solvent (Group 2), standard auxin (Group 3 ), and metal salt (Group 4). At $1 \times 10^{-5} \mathrm{M}$ concentration, the percentage germination is less, while it is good and almost equal at $1 \times 10^{-6}$ and $1 \times 10^{-7} \mathrm{M}$ concentrations.
This indicates that, at $10^{-6} \mathrm{M}$ concentration, both $\mathrm{HL}$ and $\mathrm{La}$ (III) complex have more growth promoting activity than the standard auxin used.

3.7.1. Shoot Length. At $1 \times 10^{-5} \mathrm{M}$ concentration, surprisingly Groups 5 and 6 have shown a decreased activity while at $1 \times 10^{-7} \mathrm{M}$, a significant change was observed. But at $1 \times 10^{-6} \mathrm{M}$, a significant enhancement in shoot length is observed on complexation (Group 6). The graph is given in Figure 15.

3.7.2. Root Length. At $1 \times 10^{-5} \mathrm{M}$ concentration, Group 4 has shown significant increase in root length compared to Groups 3, 5, and 6. At $1 \times 10^{-6} \mathrm{M}$, Groups 5 and 6 have shown significant enhancement in root length compared to even Group 3 (the commercial auxin). When compared 
among the Groups 5 and 6, the activity has enhanced on complexation (Group 6). A similar observation is made at $1 \times 10^{-7} \mathrm{M}$ concentration, but the extent of enhancement is less compared to that at $1 \times 10^{-6} \mathrm{M}$. The comparative graph is given in Figure 16.

\section{Conclusion}

A series of lanthanide complexes were prepared by treating novel 2-\{[2-(2, 4-dichloro-phenoxy)-acetyl]-hydrazonomethyl $\}$-phenoxy)-acetic acid with lanthanide(III) nitrates. The structure of HL was confirmed by various spectroscopic techniques. NMR spectral data of HL reveal its existence in $\mathrm{E}$ and $\mathrm{Z}$ isomeric forms in solution at room temperature. The coordination mode of ligand is well established from elemental analysis, molar conductivity, IR, NMR, mass, electronic spectral, and thermal studies. The results confirm that ligand has coordinated in bidentate fashion through carboxylic acid group via deprotonation. Based on spectral and analytical results, tentative structure for complexes is given in Figure 14. The results obtained on plant growth activity indicate that germination percentage is more at $1 \times 10^{-6} \mathrm{M}$ and $1 \times 10^{-7} \mathrm{M}$ concentrations. When compared between the standard, HL and lanthanum(III) complex, an enhancement in the plant growth activity was observed on complexation and the best activity was observed at $10^{-6} \mathrm{M}$ concentration.

\section{Acknowledgment}

The authors greatly acknowledge the University Grant Commission, New Delhi, for the financial support.

\section{References}

[1] Z. M. Wu, X. K. Tang, and Z. W. Jia, "Studies of rare earth elements on role of enhancing production in agriculture. I. Effect of rare earth elements on some physiological process in crop," Journal of the Chinese Rare Earth Society, vol. 2, pp. 75-79, 1984.

[2] S. Q. Zheng, T. Peng, and Z. D. Zhang, "Effect of rare earths on the seed germination and the roots growth of several vegetables," China Raises Rare-Earth, vol. 14, pp. 60-61, 1993.

[3] X. Pang, D. Li, and A. Peng, "Application of rare-earth elements in the agriculture of china and its environmental behavior in soil," Journal of Soils and Sediments, vol. 1, no. 2, pp. 124-129, 2001.

[4] F. Zeng, H. E. Tian, Z. Wang et al., "Effect of rare earth element europium on amaranthin synthesis in amarathus caudatus seedlings," Biological Trace Element Research, vol. 93, no. 1-3, pp. 271-282, 2003.

[5] F. Hong, W. Song, Z. Wan et al., "Effect of $\mathrm{La}$ (III) on the growth and aging of root of loquat plantlet in vitro," Biological Trace Element Research, vol. 104, no. 2, pp. 185-191, 2005.

[6] F. Hong, L. Wang, and C. Liu, "Study of lanthanum on seed germination and growth of rice," Biological Trace Element Research, vol. 94, no. 3, pp. 273-286, 2003.

[7] K. Lu, Z. Chang, B. Chen, D. Guo, J. Zheng, and K. Wang, "Hormone like effect of rare earth elements on plant," Beijing YiKe DaXue XueBao, vol. 29, 1997.
[8] B. Wen, D. A. Yuan, X. Q. Shan, F. L. Li, and S. Z. Zhang, "The influence of rare earth element fertilizer application on the distribution and bioaccumulation of rare earth elements in plants under field conditions," Chemical Speciation and Bioavailability, vol. 13, no. 2, pp. 39-48, 2001.

[9] H. Fashui, "Study on the mechanism of cerium nitrate effects on germination of aged rice seed," Biological Trace Element Research, vol. 87, no. 1-3, pp. 191-200, 2002.

[10] H. Fashui, W. Zhenggui, and Z. Guiwen, "Effect of lanthanum on seed germination of rice," Biological Trace Element Research, vol. 75, no. 1-3, pp. 205-213, 2000.

[11] H. Wenmian, F. Jian, and Z. Zhengzhi, "Effect of auxinhormone lanthanide complexes on the growth of wheat coleoptile," Biological Trace Element Research, vol. 64, no. 1-3, pp. 27-35, 1998.

[12] K. B. Gudasi, R. V. Shenoy, R. S. Vadavi et al., "Lanthanide(III) and yttrium(III) complexes of benzimidazole-2-acetic acid: synthesis, characterisation and effect of La(III) complex on germination of wheat," Bioinorganic Chemistry and Applications, vol. 2006, Article ID 75612, 8 pages, 2006.

[13] T. Gaspar, C. Keveks, C. Penel, H. Greppin, D. M. Reid, and T. A. Thorpe, "Plant hormones and plant growth regulators in plant tissue culture," In Vitro Cellular and Developmental Biology-Plant, vol. 32, no. 4, pp. 272-289, 1996.

[14] P. H, Moura-Costa, and L. Lundoh, "The effects of auxins (IBA, NAA and 2,4-D) on rooting of Dryobalanops lanceolata (kapur, Dipterocarpaceae) cuttings," Journal of Tropical Forest Science, vol. 7, no. 2, pp. 338-340, 1994.

[15] M. Katayama, "Synthesis and biological activities of 4chloroindole-3-acetic acid and its esters," Bioscience, Biotechnology, and Biochemistry, vol. 64, no. 4, pp. 808-815, 2000.

[16] T. Ulven, J. M. Receveur, M. Grimstrup et al., "Novel selective orally active CRTH2 antagonists for allergic inflammation developed from in silico derived hits," Journal of Medicinal Chemistry, vol. 49, no. 23, pp. 6638-6641, 2006.

[17] F. J. Welcher, The Analytical Uses of EDTA, Van Nostrand, New York, NY, USA, 1965.

[18] W. L. F. Armarego and D. D. Perrin, Purification of Laboratory Chemicals, Butterworth-Heineman, Boston, Mass, USA, 4th edition, 1996.

[19] T. Liu, G. Duan, Y. Zhang, J. Fang, and Z. Zeng, "Synthesis and characterization of the luminescent lanthanide complexes with two similar benzoic acids," Spectrochimica Acta A, vol. 74, no. 4, pp. 843-848, 2009.

[20] E. J. Warham, L. D. Butler, and B. C. Sutton, Seed Testing of Maize and Wheat: A Laboratory Guide, CIMMYT, Texcoco, Mexico; CAB International, London, UK, 1995.

[21] D. L. Howard and H. G. Kjaergaard, "Influence of intramolecular hydrogen bond strength on $\mathrm{OH}$-stretching overtones," Journal of Physical Chemistry A, vol. 110, no. 34, pp. 10245-10250, 2006.

[22] L. E. Niu, Y. Yang, X. H. Qi, and X. Liang, "Synthesis and spectroscopic studies of lanthanide(III) complexes with (Z)-4OXO-4-(phenylamino) but-2-enoic acid," Synthesis and Reactivity in Inorganic and Metal-Organic Chemistry, vol. 39, no. 1, pp. 1-5, 2009.

[23] H. M. Ye, N. Ren, J. J. Zhang, S. J. Sun, and J. F. Wang, "Crystal structures, luminescent and thermal properties of a new series of lanthanide complexes with 4-ethylbenzoic acid," New Journal of Chemistry, vol. 34, no. 3, pp. 533-540, 2010. 
[24] H. A. Azab, S. A. El-Korashy, Z. M. Anwar, B. H. M. Hussein, and G. M. Khairy, "Synthesis and fluorescence properties of Euanthracene-9-carboxylic acid towards $\mathrm{N}$-acetyl amino acids and nucleotides in different solvents," Spectrochimica Acta A, vol. 75, no. 1, pp. 21-27, 2010.

[25] G. B. Deacon and R. J. Phillips, "Relationships between the carbon-oxygen stretching frequencies of carboxylato complexes and the type of carboxylate coordination," Coordination Chemistry Reviews, vol. 33, no. 3, pp. 227-250, 1980.

[26] S. M. Shia, Z. F. Chen, Y. C. Liu, L. Li Mao, H. Liang, and Z. Y. Zhou, "Synthesis and crystal structures of lanthanide complexes with foliage growth regulator: phenoxyalkanoic acid," Journal of Coordination Chemistry, vol. 61, no. 17, pp. 2725-2734, 2008.

[27] I. Georgieva, I. Kostova, N. Trendafilova, V. K. Rastogi, and W. Kiefer, "DFT, IR, Raman and NMR study of the coordination ability of coumarin-3-carboxylic acid to $\operatorname{Pr}(\mathrm{III})$," Journal of Molecular Structure, vol. 979, no. 1-3, pp. 115-121, 2010.

[28] A. Tine, P. Guillaume, A. Massat, and J. J. Aaron, "Infrared study of indolecarboxylic acids associations with lanthanide acetates," Spectrochimica Acta A, vol. 54, no. 10, pp. 1451-1459, 1998.

[29] T. F. Zafiropoulos, J. C. Plakatouras, and S. P. Perlepes, "Preparation and properties of complexes of lanthanide(III) salts with n-(2-pyridyl) pyridine-2' -carboxamide," Polyhedron, vol. 10, no. 20-21, pp. 2405-2415, 1991.

[30] K. Nakamoto, Infra-Red and Raman Spectra of Complex Inorganic and Coordination Compounds, Part B, John Wiley \& Sons, New York, NY, USA, 5th edition, 1997.

[31] A. Iqbal, H. L. Siddiqui, C. M. Ashraf, M. Ahmad, and G. W. Weaver, "Synthesis, characterization and antibacterial activity of azomethine derivatives derived from 2-formylphenoxyacetic acid," Molecules, vol. 12, no. 2, pp. 245-254, 2007.

[32] A. Yeh, C. Y. Shih, L. L. Lin, S. J. Yang, and C. T. Chang, "Variable-temperature NMR studies of 2-(pyridin-2-yl)-1hbenzo[d]imidazole," Life Science Journal, vol. 6, no. 4, pp. 1-4, 2009.

[33] R. R. Gardner, S. L. McKay, and S. H. Gellman, "Solventdependent stabilization of the $\mathrm{E}$ configuration of propargylic secondary amides," Organic Letters, vol. 2, no. 15, pp. 2335-2338, 2000.

[34] T. A. Yousef, G. M. Abu El-Reash, T. H. Rakha, and U. El-Ayaan, "First row transition metal complexes of (E)-2-(2-(2hydroxybenzylidene) hydrazinyl)-2-oxo-N-phenylacetamide complexes," Spectrochimica Acta Part A, vol. 83, no. 1, pp. 271-278, 2011.

[35] B. Yan, H. J. Zhang, G. L. Zhou, and J. Z. Ni, "Different thermal decomposition process of lanthanide complexes with N-phenylanthranilic acid in air and nitrogen atmosphere," Chemical Papers, vol. 57, no. 2, pp. 83-86, 2003.

[36] Y. T. Yang and S. Y. Zhang, "Study of lanthanide complexes with salicylic acid by photoacoustic and fluorescence spectroscopy," Spectrochimica Acta A, vol. 60, no. 8-9, pp. 2065-2069, 2004.

[37] X. L. Tang, W. Dou, S. W. Chen, F. F. Dang, and W. S. Liu, "Synthesis, infrared and fluorescence spectra of lanthanide complexes with a new amide-based 1,3,4-oxadiazole derivative," Spectrochimica Acta A, vol. 68, no. 2, pp. 349-353, 2007. 

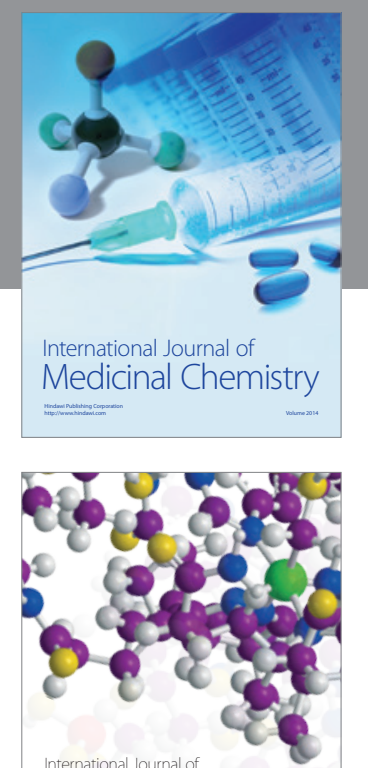

\section{Carbohydrate} Chemistry

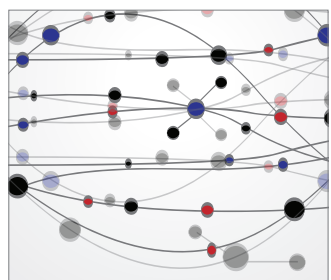

The Scientific World Journal
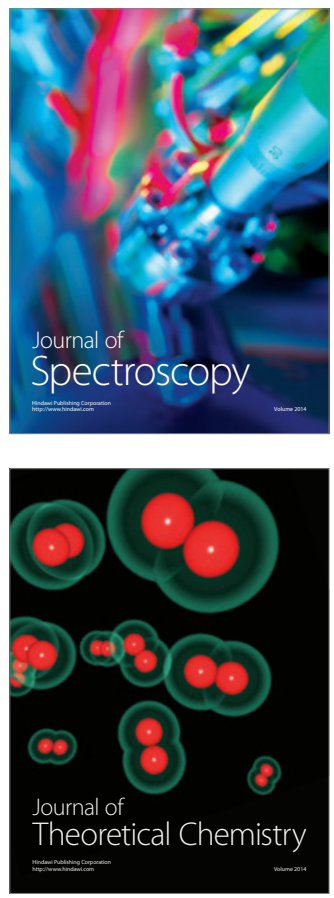
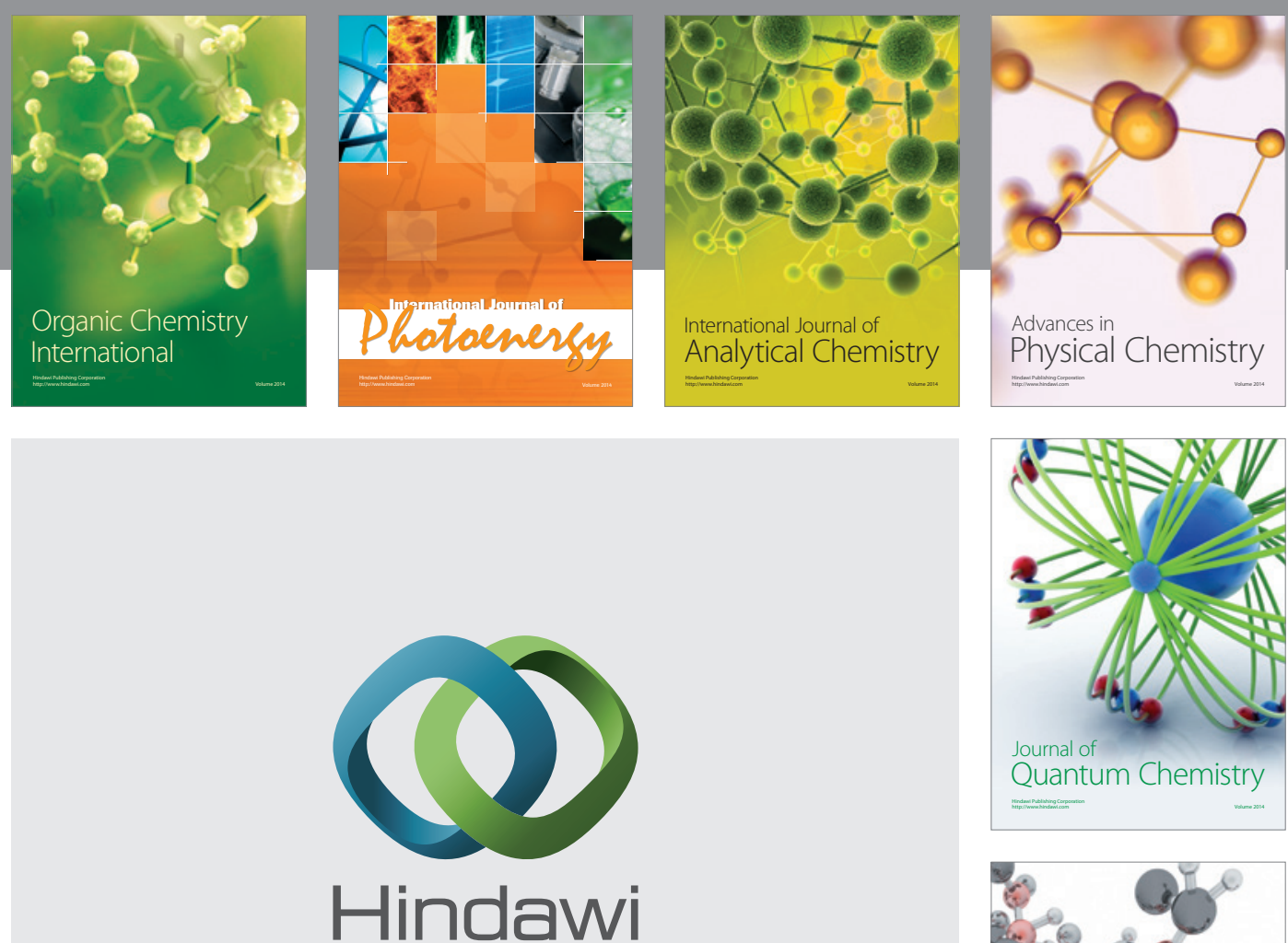

Submit your manuscripts at

http://www.hindawi.com

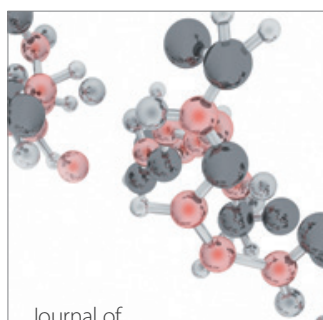

Analytical Methods

in Chemistry

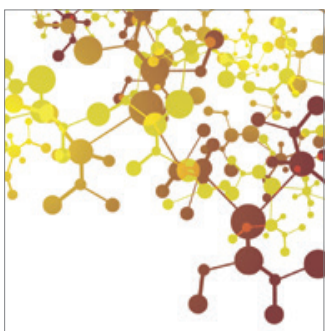

Journal of

Applied Chemistry

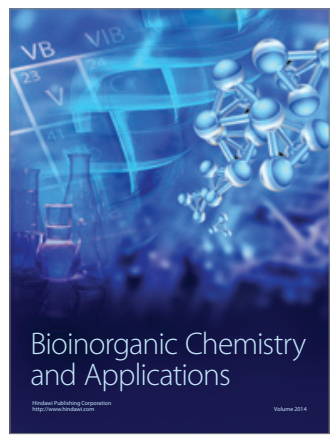

Inorganic Chemistry
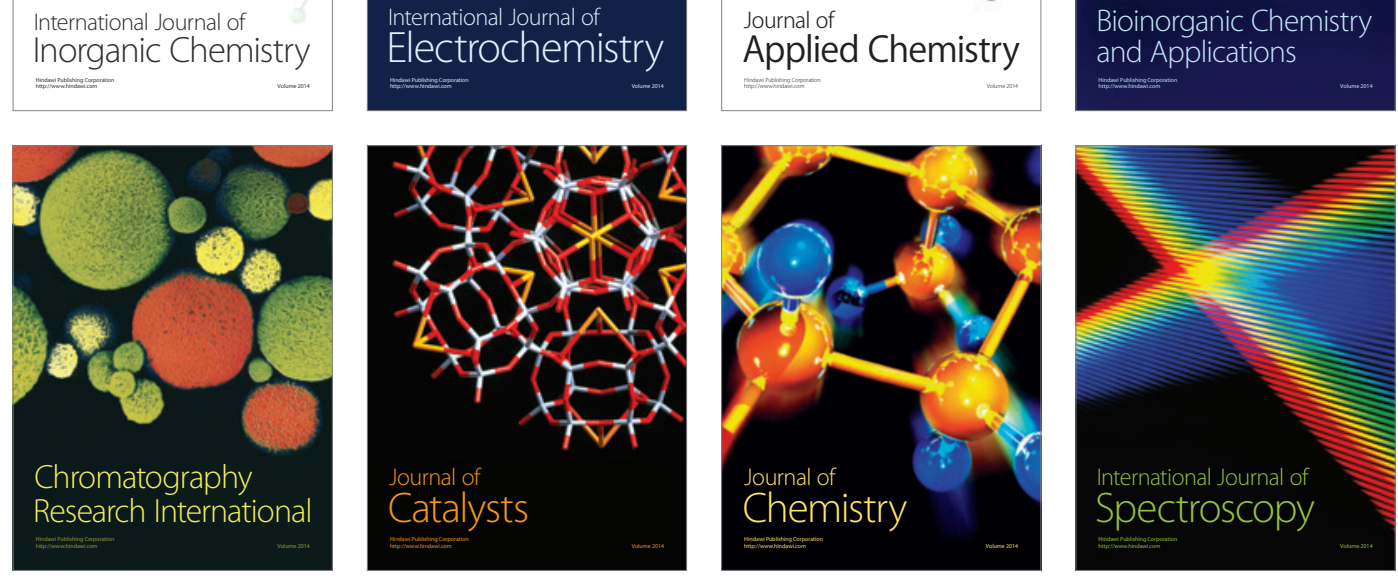